\title{
VOLCANOES, an Excellent Indicator of Heat within the Earth
}

\author{
Dr. (Prof.) V.C.A. Nair* \\ Educational Physicist, Counselor, Research Guide for Physics at Shri J.J. T. University, \\ Rajasthan-333001, India \\ *nairvca39@gmail.com
}

\begin{abstract}
The paper is dedicated to Ruaumoko the Maori God of Volcanoes. To start with, a historical account of some ancient legends regarding volcanoes is given. There is a description of eruption of a volcano with special reference to the eruption of Mount Vesuvius. Formation of magma in the Earth In the review of literature, some research papers of few eminent authors pertaining to volcanic eruption precursors, magma chambers intrusion of magma, magma wagging, velocity of eruption and quantity of eruption are considered.
\end{abstract}

Key Words: Dense Rock Equivalent, Eruption of Mount Vesuvius, Lava, Magma, Magma Chamber, Magma Reservoir, Magma wagging, Plate Tectonic theory, Ring of Fire, Volcanic eruptions, Volcanic Explosive Index (VEI)

\section{INTRODUCTION}

1.1 Dedication:This Research Paper is dedicated to Ruaumoko (Fig. 1) the Maori God of Volcanoes. It is believed by the island tribes, Maoris of New Zealand that Ruaomoko is a God of Volcanoes, Earthquakes and Seasons. He is the youngest son of Ranginui (the sky father) and Papatuanuku (the Earth mother. His wife is Hine-Nui-Te-Po, the Goddess of Death.

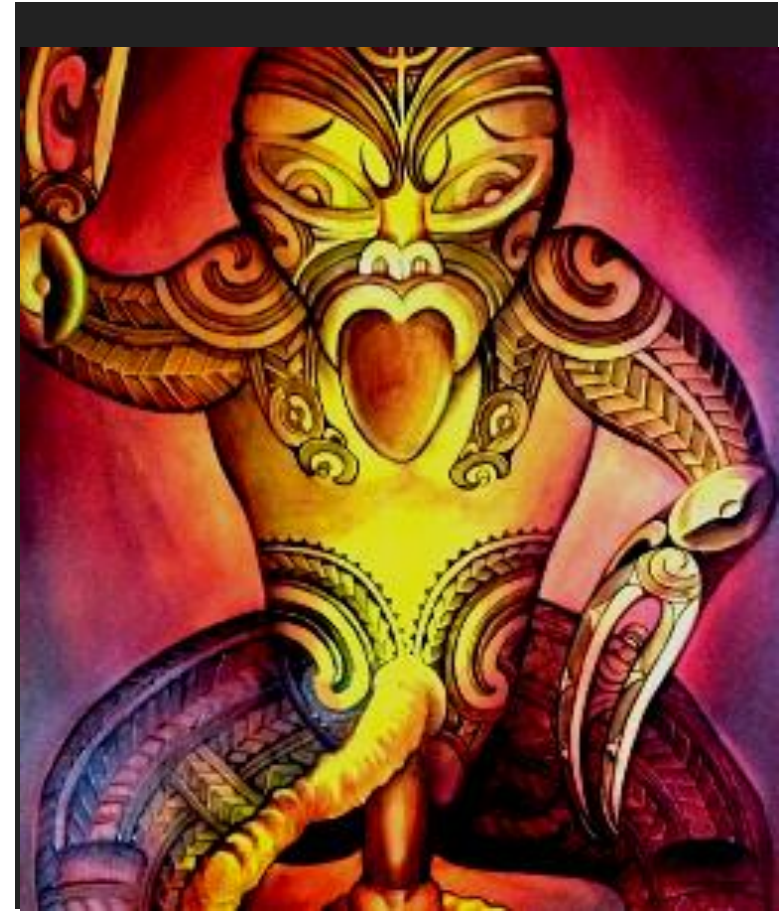

Fig.1 Ruaumoko, the Maori God of Volcanoes

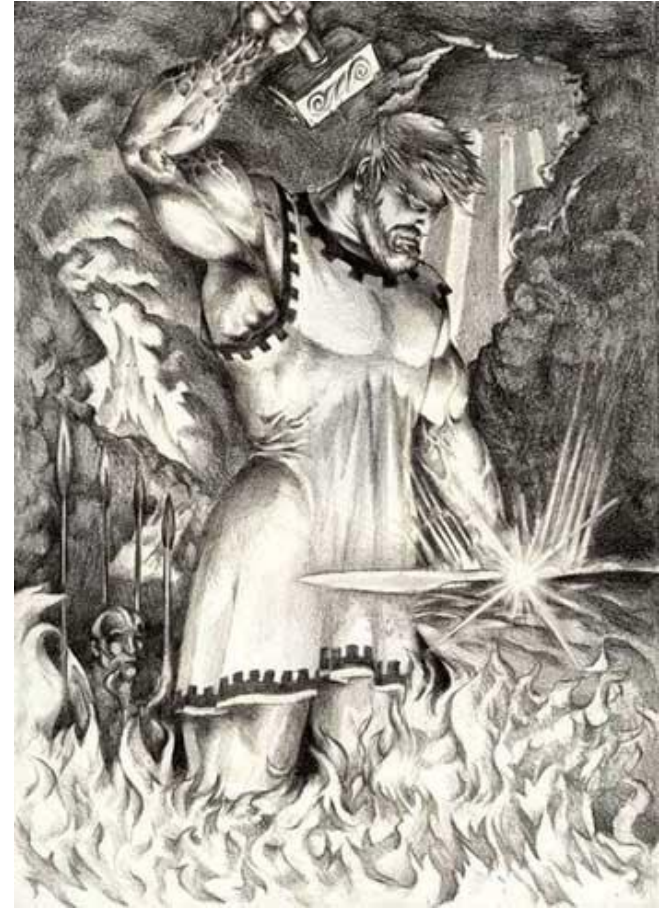

Fig.2 Volcan, the blacksmith of the Roman Gods

1.2 Historical: Like Earthquakes, Tsunamis, Tides and Clouds, Volcanoes are theresults of a type of physical processes that take place inside the Earth. Janine L. Kavanagh, et.al [9], Lady Gryphon [11] and Paul W. Taylor [13] have given a good deal of information regarding the ancient belief and history of volcanoes. The Maoris used to worship Ruaumoko (Fig.1) the God of volcanoes and earthquakes in order to get themselves protected from the fury of earthquakes and volcanoes. 


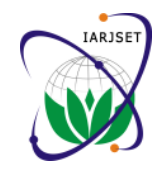

\section{IARJSET \\ International Advanced Research Journal in Science, Engineering and Technology \\ ISO 3297:2007 Certified \\ Vol. 5, Issue 5, May 2018}

${ }^{6.3}$ Many ancient accounts ascribe volcanoes to supernatural causes such as the action of Gods or demigods. According to ancient Greeks, the capricious power of volcanoes could only be explained as acts of Gods.

Greek natural philosophers from the $5^{\text {th }}$ and $4^{\text {th }}$ century BC such as Anaxagoras (510-428 BC), Democritus (460370 BC) and Plato (428-348 BC) proposed that volcanic eruptions were caused by "Great Winds inside the Earth", an idea that was supported by Aristotle (384-322 BC). The study of volcanoes is founded on eye witness accounts and field observations of activity beginning in Iataly with the descriptions of Pliny the younger of the eruptions of Vesuvius in $79 \mathrm{AD}$. Centuries later, William Hamilton (a pioneer in volcanology) gained recognition for his descriptions of the eruption of Vesuvius in 1767.

The German astronomer, Johannes Kepler (1571-1630) believed that volcanoes are the ducts for the earth's tears. An early idea counter to this was proposed by Jesuit Kircher (1602-1680), who witnessed the eruption of Mount Etna and Stromboli, then visited the crater of Vesuvius and published his view of an earth with a central fire connected to numerous others caused by the burying of sulphur, bitumen and coal.

The word, 'Volcano' is named after the small island of Vulcano in the Mediterranean Sea of Sicily. Vulcan is the blacksmith of the Roman Gods (Fig.2). Centuries ago the Romans believed that Vulcano was the chimney of forge of Vulcan. It is believed that Vulcan used to prepare weapons for Mars the God of wars on orders from Jupiter, the king of Gods. The molten lava and the fragments that came out from the volcano, it is believed that they are from the forge of Vulcan as he beat out thunderbolts in the preparation of weapons. The people in Polynesia attributed the eruptive activity to the beautiful but wrathful Pele, the Godess of volcanoes whenever she was angry or spiteful.Pele is one of the most well known and revered in Hawaiian mythology. As a sign of respect you may hear her referred to as Madame Pele or Tutu Pele. She is a goddess of fire, lightning, dance, wind, volcanoes and violence. Her poetic name is Ka wahine 'ai honua or the woman who devours the land. She is both a creator and destroyer. She throws molten fountains into the air and governs the great flows of lava. With her power over the volcanoes, she created the Hawaiian Islands and to this day, she has been known to reveal herself throughout the beautiful islands she crafted herself. Here is a poem:

No Kahiki mai ka wahine `o Pele,

Mai ka `aina mai o Polapola,

Mai ka punohu a Kane,

Mai ke ao lapa i ka lani.

\section{Translation:}

The woman Pele comes from Kahiki,

From the land of Polapola,

From the rising mist of Kane,

From the clouds that move in the sky.

According to legend, Pele lives in one of the most active volcanoes in the world. She calls the summit of Kilauea, in Halema'uma'u crater home

As we talk of fire as a good servant and a bad master, volcanoes are the same. They destroy and also they create. The awesome destructive power is revealed in the catastrophic eruption of Mount St. Helens on 18 May 1980. But, for a long time unknown to man, volcanoes have played a key role in forming and modifying the planet upon which we live. According to geologists and oceanographers, about $75 \%$ of the earth's surface including that of the sea bed is of volcanic origin. It is believed that gaseous emissions from volcanic vents over millions of years formed the earth's oceans and atmosphere, the vital necessities for human and animal life. The present majestic land shapes and fertile soils are the results of several volcanic eruptions of the past.

Today we know that there is nothing heavenly or divine in the earthquakes and volcanoes. They are the result of physical processes that take place within the earth. A volcano erupts and nobody on earth can stop it, that is, there is no prevention. Even though it is disastrous, an erupting volcano is a beauty of nature.

\section{REVIEW OF LITERATURE}




\section{International Advanced Research Journal in Science, Engineering and Technology}

ISO 3297:2007 Certified

Vol. 5, Issue 5, May 2018

\section{HEAT WITHIN THE EARTH}

2.1 The Possible temperatures within the Earth: Figures (3) [3] and (4) [20] show the possible temperatures within the Earth

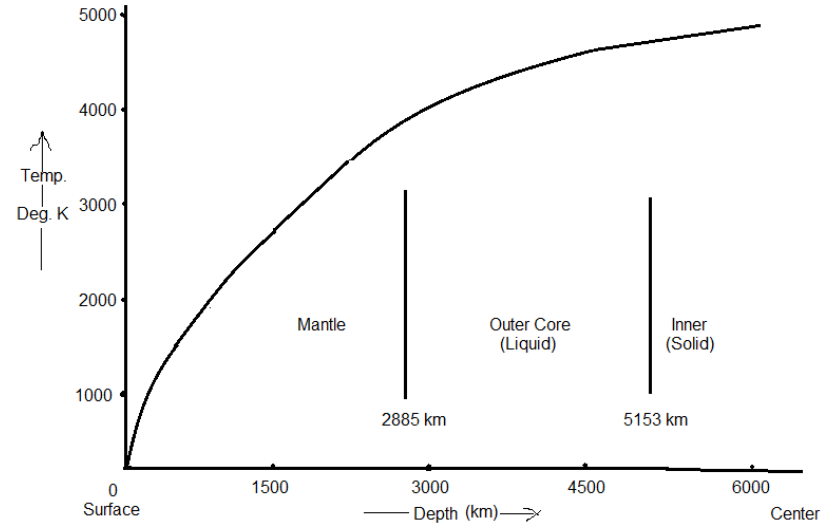

Fig.3 Possible temperature distribution within the Earth [3]

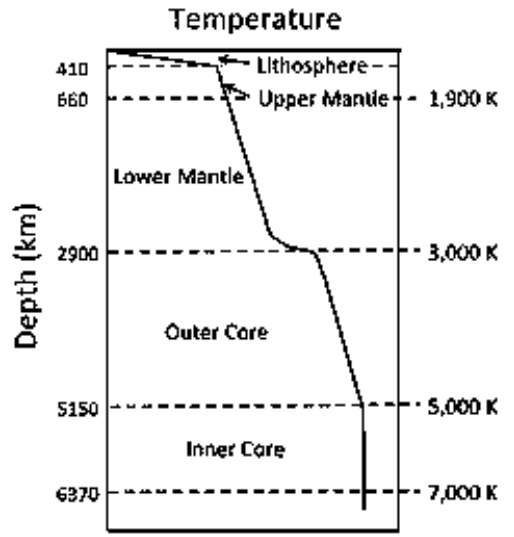

Fig.4. Temperature profile of the inner

Earth, schematic view (estimated).[20]

In 1644 Rene Descartes (1596-1650) the French philosopher and mathematician in his Principia Philosophiae presented his theory that the Earth could have started as a molten mass, the crust forming a part of the cooling process. In Fig.5 is shown a 1664 vision of Earth's interior, subterranean lakes and rivers surround a central fiery core.[2]

\subsection{The realization of heat within the Earth:}

2.2.1 Geysers and hot water springs: The presence of geysers and hot water springs on various parts of the Earth reveal the internal heat of the Earth.

2.2.2Geothermal Exploration: In some parts of US and in Iceland few kilometers inside the Earth are drilled so as to explore the subsurface in search of viable active geothermal regions with the goal of building a geothermal power plant, where hot fluids drive turbines to create electricity. This is an experimental and successful realization of the internal heat of the Earth. The drawback in this process is that it is highly expensive and difficult to drill beyond, say, some 10 $\mathrm{km}$ or more. Imagine going to the center of the Earth which is some $6370 \mathrm{~km}$ (Radius of Earth) from the surface of Earth - A real impossibility indeed !. Hence the most ideal and an excellent indicator of heat within the Earth is the eruption of a volcano, the magma of which comes out from the upper mantle about $2000 \mathrm{~km}$ from the surface.

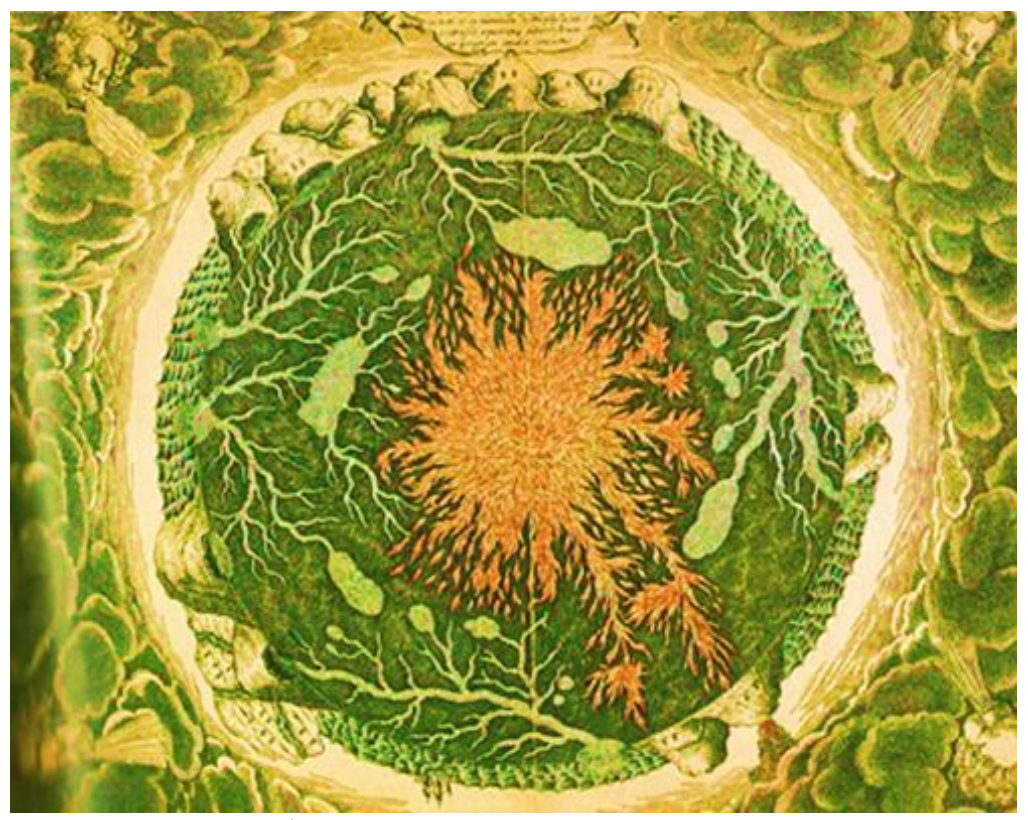

Fig.5 An artist's ancient view of the interior of Earth [2] 


\section{IARJSET \\ International Advanced Research Journal in Science, Engineering and Technology \\ ISO 3297:2007 Certified \\ Vol. 5, Issue 5, May 2018}

2.3. Volcanic Eruptions: As mentioned volcano is an excellent indicator of heat inside the Earth and hence at the outset it is of interest for us to start with the actual eruption of a volcano. In the Fig. 6 is shown the eruption details of a composite volcano also known as a strato volcano. Two such volcanoes, Mount Shastha and Mount Lassen are situated in northern California, US. The author had a close look of these volcanoes on 15 August 2014 (See photos in the Epilogue). The Figure is obtained from Google Search in which the out-flow of magma which is very important is found missing and hence added at the appropriate place by author. The labeling of the diagram is self- explanatory and when one tries to have a close look will find that the magma chamber and magma reservoir are shown as the same. Hence I would like to exercise the following caution to the readers.

2.3.1Caution over a likely Confusion: After going through a number of research papers and articles on the subject of this paper I have found that many authors have inadvertently used the words, "Magma Chamber" and "Magma Reservoir" synonymously. I would like to caution the readers regarding a likely confusion that might arise and present here my understanding of the same. Readers are requested to contact me with their comments, if any, on my e-mail.

i) An on-line information on the topic is as follows:

"A magma chamber may be defined as a partially or totally molten body located in the earth's crust and capable of supplying magma to volcanic eruptions. An active magma chamber acts as a sink for magma from a deeper reservoir, whichis commonly located in the lower crust or the upper mantle.-Sep.26, 2013

A British Dictionary definition is as follows:

ii) a reservoir of magma in the earth's crust where the magma may reside temporarily on its way from the upper mantle to the earth's surface

"A review of laboratory and numerical modeling in volcanoes" ByJanine L. Kavanagh, Samanthaa L.Engwell and Simon A. Martin, Solid Earth 9, p. 531-571..

Item 5 Magma Chambers p.539.reads:

iii) The largest accumulation of magma on Earth are thought to occur in deep reservoirs called magma chambers that have the potential to feed volcanic eruptions or sill to form a pluton

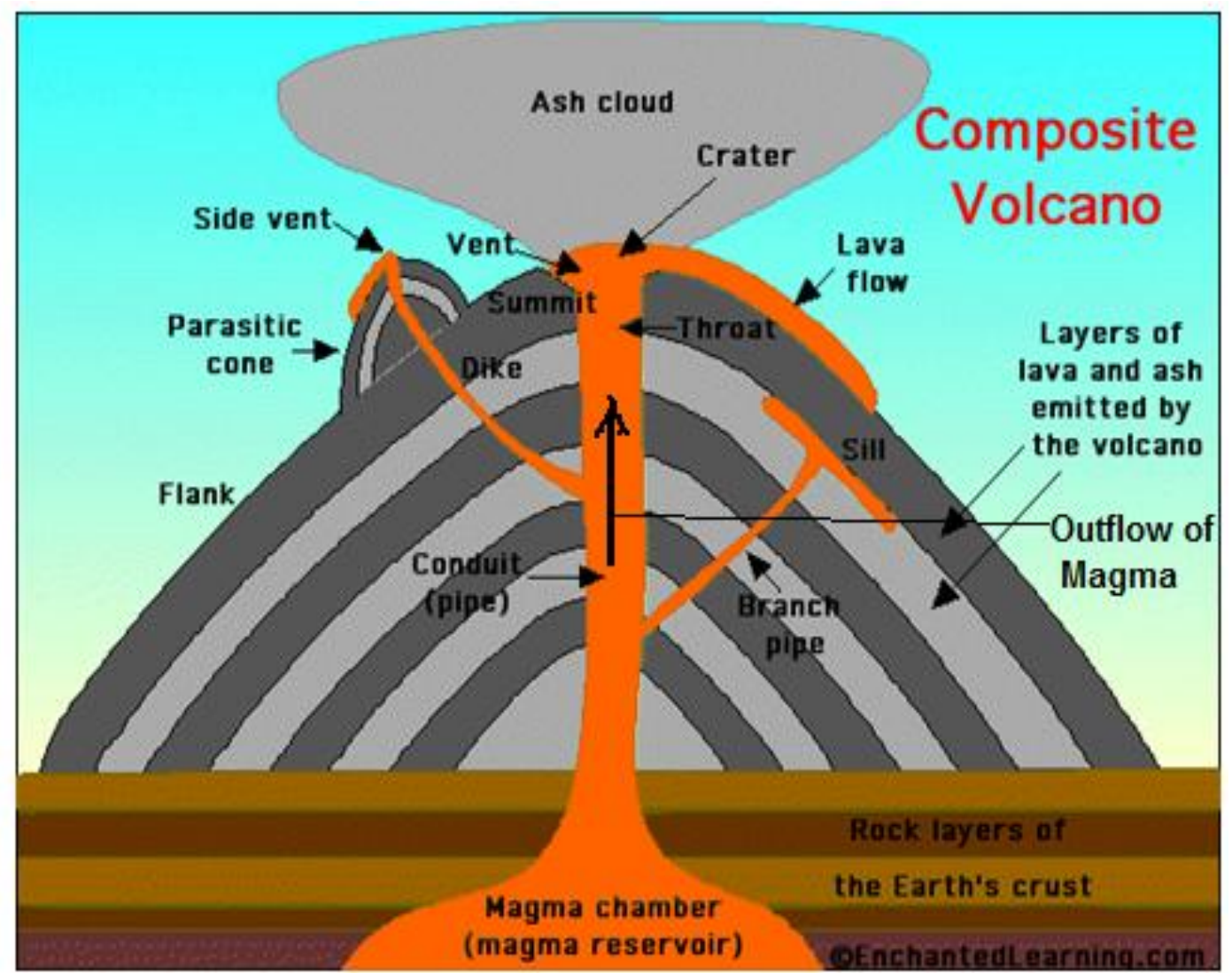

Fig.6 Illustration of Eruption of a Volcano (Picture Credit: Enchanted learning.com) 


\section{International Advanced Research Journal in Science, Engineering and Technology}

ISO 3297:2007 Certified

Vol. 5, Issue 5, May 2018

The last one iii) in the above indicating that deep reservoirs are called as magma chambers makes it controversial. Following "Cause and Effect" formalism the cause for eruption is intrusion of magma to the magma chamber from the reservoir. The size of the reservoir is so large that any stray intrusion of magma to the reservoir from the upper mantle will only add to the quantity of magma in it and will not have any effect related to eruption. It will be something like a frog entering a large well.

2.4 Eruption of Mount Vesuvius in Italy: No volcanologist can ever miss mentioning the eruption of Mount Vesuvius on 24/25 August 79 AD. In Fig.7 is shown its geographical location and an artist's view on the right.
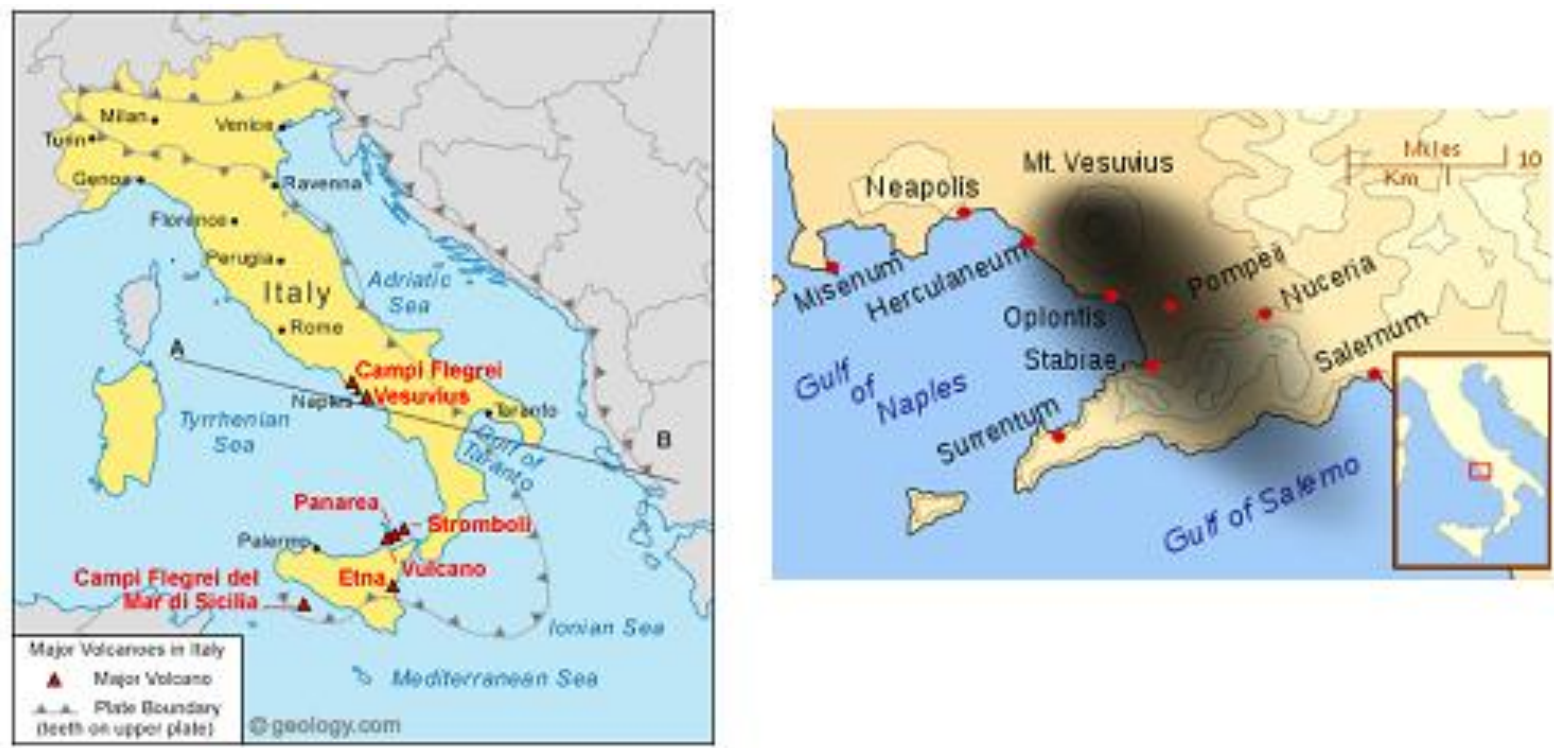

Fig.7 The location of Vesuvius in Italy (left). Artist's view of the thick cloud of smoke during Eruption (Right) [19]

Mount Vesuvius, a volcano in modern-day Italy, erupted in $79 \mathrm{AD}$ in one of the most catastrophic volcanic eruptions in European history. Historians have learned about the eruption from the eyewitness account of Pliny the Younger, a Roman administrator and poet.The event is the namesake for the Vesuvian type of volcanic eruption.

Mount Vesuvius with an elevation of about 1280 meter spewed forth a deadly cloud of tephra and gases to a height of 33 kilometres $(21 \mathrm{mi}$ ), ejecting molten rock, pulverized pumice and hot ash at the rate of 1.5 million tons per second, ultimately releasing 100,000 times the thermal energy of the Hiroshima-Nagasaki bombings. Several Roman settlements were obliterated and buried underneath massive pyroclastic surges and ashfall deposits, the best known being Pompeii and Herculaneum.

The total inhabitants of the cities were 16,000-20,000; the remains of about 1,500 people have been found at Pompeii and Herculaneum, but the overall death toll is still unknown.

The investigators reconstruct the sequence of volcanic events as follows. On the first day of the eruption a fall of white pumice containing clastic fragments of up to 3 centimetres ( 1 in) fell for several hours. It heated the roof tiles to 120 $140{ }^{\circ} \mathrm{C}\left(250-280^{\circ} \mathrm{F}\right)$. This period would have been the last opportunity to escape. Subsequently, a second column deposited a grey pumice with clastics up to $10 \mathrm{~cm}$ (4 in), temperature unsampled, but presumed to be higher, for 18 hours. These two falls were the Plinian phase.The overall impact was that the eruption buried the Roman settlements of Pompeii, Herculaneum, Oplomtis and Stabiae..

Kenneth Hamblin and Eric Christiansen [2] adds the following: "Vesuvius erupted and buried Pompeii, Italy with ash in $79 \mathrm{AD}$. It is one oif the several composite volcanoes that lie above a westward-dipping subduction zone beneath Italy. People asphyxiated by poisonous gas during the eruption were 


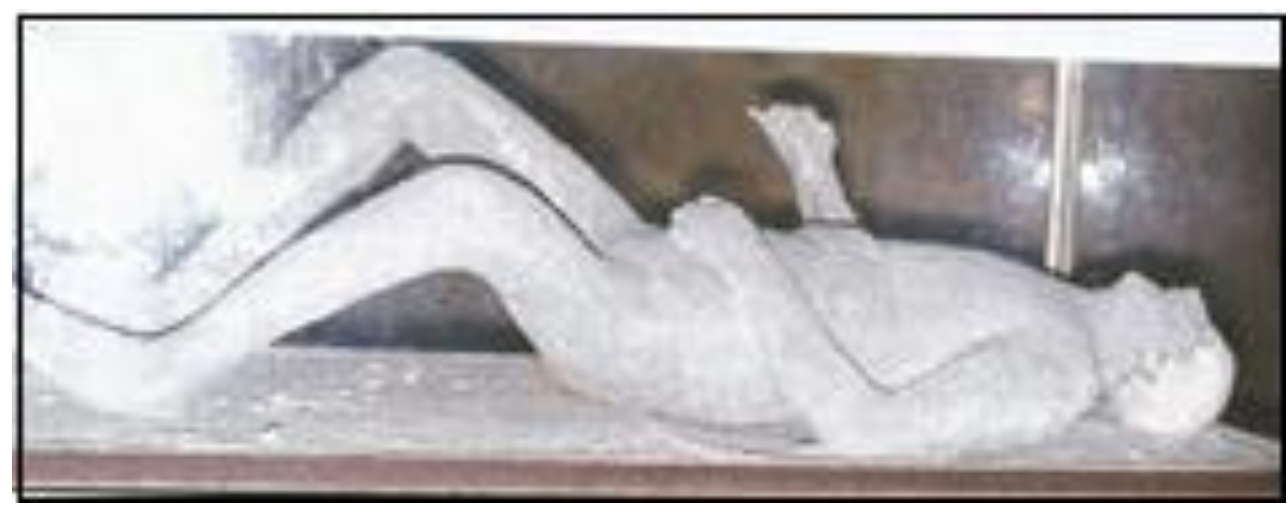

Fig.7 Ash cavity left by a decomposed body during a Vesuvius eruption

buried in the ash. Eventually, the bodies decomposed, leaving cavities in the ash. By filling these cavities with plaster, archeologists have made detailed casts. (Fig.7). Excavations provide important insights into volcanic activity at convergent plate margins.

The Volcanic Explosive Index (VEI) [5] of the Vesuvius eruption is 5 whereas the Tambora eruption in the year 1815 in Indonesia had a VEI value 7. It was so big that the explosion could be heard over $2000 \mathrm{~km}$ away, and the 200 million tones of sulphur that were emitted spread across the globe lowering global temperature by $2^{\circ} \mathrm{C}$.. The eruption caused thousands of deaths, and failure of crops which led to widespread famine.

2.5 The Physics of eruption: The Physics of eruption of a volcano can be briefed as follows:

Due to buoyancy and gas pressure, the molten rocks being lighter than the surrounding solid rock, forces ash. its way upward and tries to find some weak point on the Earth's crust and the eruption starts. The molten rock comes out through the vent as lava and lighter ones may shoot out violently into the air as thick clouds of lava fragments. Some larger and heavy ones fall back into the vent. The lighter ones get accumulated around the vent. The accumulation of heavy fragments around the vent start flowing downwards due to gravity. Some of the lighter ejected ones are carried by the wind and later fall on the ground many kilometers away. The finest gas-like particles escape to the atmosphere and may reach any part of the globe by stratospheric winds before getting settled.

The magma consists of crystals, fragments of surrounding un-melted rocks and dissolved gases, but it is basically a liquid composed mainly of oxygen, silicon, aluminium, magnesium, calcium, sodium, potassium, titanium and manganese. After getting solidified, it forms a huge magmatic rock. Sometimes, due to high impact, the eruption column collapses creating a pyroclastic flow, wherein the gas and tephra rush down the flanks of the volcano at high speed. The pyroclastic flows are sometimes called Pyroclastic Density Currents (PDC).

\subsection{Measure of Volcanic Eruptions (Eruption Scale):[5]}

In the year 1982, Stephen Self and Chris Newhall of the University of Hawaii devised a quantity known as the Volcano Explosivity Index (VEI) which is a measure of volcanic eruptions. This is different from Volcanicity which is the level of power of a volcano. The tremor signal and properties vary with the intensity of explosive eruptions. The VEI is usually represented in terms of a scale of 8 and is shown in Table-1. The VEI is further categorized into two. That is the low intensity events where VEI $<3$ and high intensity events where VEI $>3$.

Table No.1Source: Volcano World, (an educational site at the University of North Dakota)

\begin{tabular}{|l|l|l|l|l|l|l|}
\hline VEI & Description & Plume Height & Volume & Classification & How often & Example \\
\hline $\mathbf{0}$ & non-explosive & $<100 \mathrm{~m}$ & $1000 \mathrm{~s} \mathrm{~m}^{3}$ & Hawaiian & daily & Kilauea \\
\hline $\mathbf{1}$ & gentle & $100-1000 \mathrm{~m}$ & $10000 \mathrm{~s} \mathrm{~m}^{3}$ & Haw/Strombolian & daily & Stromboli \\
\hline $\mathbf{2}$ & explosive & $1-5 \mathrm{~km}$ & $1000000 \mathrm{~s} \mathrm{~m}^{3}$ & Strom/Vulcanian & weekly & Galeras, 1992 \\
\hline $\mathbf{3}$ & severe & $3-15 \mathrm{~km}$ & $10000000 \mathrm{~s} \mathrm{~m}^{3}$ & Vulcanian & yearly & Ruiz, 1985 \\
\hline $\mathbf{4}$ & cataclysmic & $10-25 \mathrm{~km}$ & $100000000 \mathrm{~s} \mathrm{~m}^{3}$ & Vulc/Plinian & 10 s of years & Galunggung, 1982 \\
\hline $\mathbf{5}$ & paroxysmal & $>25 \mathrm{~km}$ & $1 \mathrm{~km}^{3}$ & Plinian & 100s of years & St. Helens, 1981 \\
\hline $\mathbf{6}$ & colossal & $>25 \mathrm{~km}$ & $10 \mathrm{~s} \mathrm{~km}^{3}$ & Plin/Ultra-Plinian & 100s of years & Krakatau, 1883 \\
\hline $\mathbf{7}$ & super-colossal & $>25 \mathrm{~km}$ & $100 \mathrm{~s} \mathrm{~km}^{3}$ & Ultra-Plinian & $1000 \mathrm{~s}$ of years & Tambora, 1815 \\
\hline $\mathbf{8}$ & mega-colossal & $>25 \mathrm{~km}$ & $1000 \mathrm{~s} \mathrm{~km}^{3}$ & Ultra-Plinian & 10 000s of years & Yellowstone, 2 Ma \\
\hline
\end{tabular}


Gisselle Diamond [5] gives details of the eruption scale. The scale ranges from a 0 or 1, which are the most peaceful, small, lava eruptions, and numbers 2, 3, 4, which are the small to medium eruptions that happen maybe once a year. No. 5 on the scale are eruptions that happen every 10 years, give or take. No. 6 are eruptions that happen every 100 years. When it comes to 7, they happen every 1,000 years or so and are very destructive. No. 8 tops out the scale and these are eruptions that occurred from 73,000 years to 1 million years ago. These are eruptions that are so devastating that it could tremendously affect the earth's population. They can cause what is known as a volcanic winter. This is when the ash from the eruption is so thick that it clouds out the sun for many many years.

All these eruptions are put into this scale based on math termed as logarithms. Each number equates to an eruption that is 10 times bigger than the one before it. It only measures the content of the eruption matter that the volcano pushes out, not the mass of the eruption matter or the power behind the eruption. As of right now, scientists are trying to devise a better scale that measures eruption not by the volume or density, but by the amplitude of it. If the new scale is accepted, it can not be used for volcanoes that happened over 1 million years ago or eruptions that happened when no one was watching the actual eruption.

2.6.1.How the VEI Works: When a volcano erupts, the explosiveness is then measured. The amount of matter ejected from the volcano and how tall the clouds are then measured. The debris, such as ash, gas and rock, are lumped into one. They are known by the term Dense-Rock Equivalent, or DRE. This is then assessed to tell how much lava has been pushed out of the volcano.

2.7 Types of Volcanic Eruptions:- Each volcano is different from the other one from the point of view of the type of eruption. Each one shows a distinctive pattern of behavior. Some erupts mildly simply discharge steam and other gases whereas others extrude molten lava. The most spectacular one consists of violent explosion that blast great clouds of gas-laden debris into the air. Any volcano erupting anywhere is compared with the one already taken place elsewhere and the names are given accordingly. For example, "Strombolian", "Vulcanian", "Vesuvian", "Pelean", "Hawaiian", etc. The most powerful eruption is called "Plinian" and is really a dangerous one because of the pyroclastic flows from the vent.

\subsection{Classification of Volcanoes:-}

There are three classifications: (i) Active, (ii) Extinct and (iii) Dormant.

2.8.1 Active:- Active volcanoes are those which erupt regularly. The word, 'regularly' is a relative term. The life span may vary from months to years. Presently there are about 500 active volcanoes in the world many of them situated along the Pacific "Ring of Fire". Among this 500, about 50 of them erupt each year. The US has about 50 active volcanoes. An estimated 500 million people live near active volcanoes.

2.8.2 Extinct:- Those volcanoes which have not erupted in historical times is called 'Extinct'. They are extinct because there is no supply of lava. Again the term, 'Extinct' is relative. Due to the change in physical processes inside the earth, a volcano which is thought to be extinct, can become active; only thing is that the present generation may not live to witness the eruption. Examples of extinct volcanoes are: Many volcanoes in the Hawaiian - Emperor Seamount chain in the Pacific Ocean, Hohentwiel, Shiprock and the Zuidwal volcano in Netherlands, Edinburgh Castle in Scotland is famously located atop an extinct volcano.

2.8.3Dormant:- Those which have erupted in the past, but now quiet are called 'dormant' or 'inactive'. There is no much difference between an extinct volcano and a dormant one. It all depends on for how much long time a volcano is inactive. If it is dormant for appreciably long time, then it is said to be extinct. If the time for which it is inactive is short, then we may say it is dormant. Examples are Soufriere Hills volcano in the island of Montserrat considered to be extinct became active in the year 1995.

\section{MAGMA AND LAVA}

3.0Like Magma chamber and magma reservoir, Magma and Lava are different. 'Magma' comes from the Greek word, "Kneaded Mixture". Magma is a complex high temperature fluid substance formed out of molten rock material that commonly contains solids and gases. In the Fig.8 [2] is shown a picture of magma. Magma and lava are different in the sense that magma is turned into lava after it gets cooled and loses its dissolved gases on coming out of the vent. Thus, Lava is the extrusive equivalent of magma which over a period of time becomes an igneous rock 


\section{International Advanced Research Journal in Science, Engineering and Technology \\ ISO 3297:2007 Certified}

Vol. 5, Issue 5, May 2018

Prof Stephen A. Nelson [ ] has given some of the properties (Table No. ) of magma and its formation.

Table No.2

\begin{tabular}{|l|l|l|l|l|l|}
\hline Sr.No & Type of Magma & $\begin{array}{l}\text { Chemical } \\
\text { Composition }\end{array}$ & Temp. Range & $\begin{array}{l}\text { Density } \\
\mathrm{kg} \mathrm{m}^{-3}\end{array}$ & Viscosity \\
\hline 1 & Basaltic & $\begin{array}{l}45-55 \% \mathrm{SiO} 2 \text {, high in } \mathrm{Fe}, \mathrm{Mg}, \\
\mathrm{Ca} \text {; low in } \mathrm{K}, \mathrm{Na}\end{array}$ & $1000^{\circ} \mathrm{C}-1200^{\circ} \mathrm{C}$ & $2650-2800$ & Low \\
\hline 2 & Andesitic & $\begin{array}{l}55-65 \% \mathrm{SiO} 2, \mathrm{Traces} \text { of } \mathrm{Fe}, \\
\mathrm{Mg}, \mathrm{Ca}, \mathrm{Na}, \mathrm{K}\end{array}$ & $800^{\circ} \mathrm{C}-1000^{\circ} \mathrm{C}$ & $2450-2500$ & Medium \\
\hline 3 & Rhyolite & $\begin{array}{l}65-75 \% \mathrm{SiO} \text {; } \mathrm{Low} \text { in } \mathrm{Fe}, \mathrm{Mg}, \\
\mathrm{Ca} ; \mathrm{High} \mathrm{in} \mathrm{K}, \mathrm{Na}\end{array}$ & $650^{\circ} \mathrm{C}-800^{\circ} \mathrm{C}$ & $2180-2250$ & High \\
\hline
\end{tabular}

Chemically lava is made of the elements Silicon, oxygen, aluminum, iron, magnesium, calcium, sodium, potassium, phosphorus and titanium with other elements in traces.

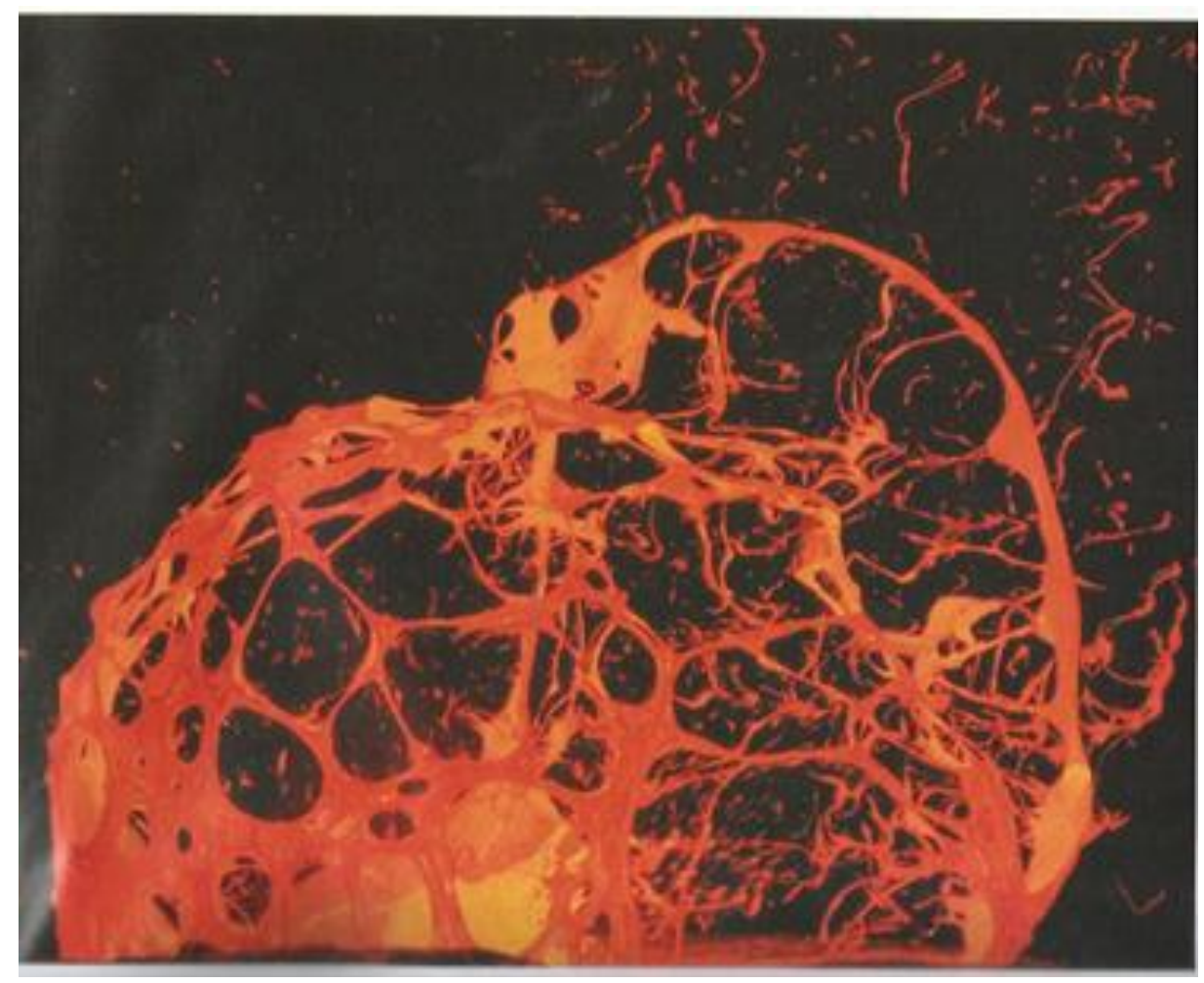

Fig.8 A Picture of Magma [2]

3.1How Magma is produced in the Earth ? Earth is divided into three general layers. The core is the superheated center, the mantle is the thick, middle layer, and the crust is the top layer on which we live. Magma originates in the lower part of the Earth's crust and in the upper portion of the mantle. Most of the mantle and crust are solid, so the presence of magma is crucial to understanding the geology and morphologyof the mantle.Differences in temperature, pressure, and structural formations in the mantle and crust cause magma to form in different ways.

\subsubsection{Decompression Melting}

Decompression melting involves the upward movement of Earth's mostly-solid mantle. This hot material rises to an area of lower pressure through the process of convection. Areas of lower pressure always have a lower melting point than areas of high pressure. This reduction in overlying pressure, or decompression, enables the mantle rock to melt and form magma. Decompression melting often occurs at divergent boundaries, where tectonic plates separate. The rifting movement causes the buoyant magma below to rise and fill the space of lower pressure. The rock then cools into new crust. Decompression melting also occurs at mantle plumes, columns of hot rock that rise from Earth's high-pressure core to its lower-pressure crust. When located beneath the ocean, these plumes, also known as hot spots, push magma onto the seafloor. These volcanic mounds can grow into volcanic islands over millions of years of activity. 


\section{International Advanced Research Journal in Science, Engineering and Technology}

ISO 3297:2007 Certified

Vol. 5, Issue 5, May 2018

\subsubsection{Transfer of Heat}

Magma can also be created when hot, liquid rock intrudes into Earth's cold crust. As the liquid rock solidifies, it loses its heat to the surrounding crust. Much like hot fudge being poured over cold ice cream, this transfer of heat is able to melt the surrounding rock into magma. Transfer of heat often happens at convergent boundaries, where tectonic plates are crashing together. As the denser tectonic plate subducts, or sinks below, or the less-dense tectonic plate, hot rock from below can intrude into the cooler plate above. This process transfers heat and creates magma. Over millions of years, the magma in this subduction zone can create a series of active volcanoes known as a volcanic arc.

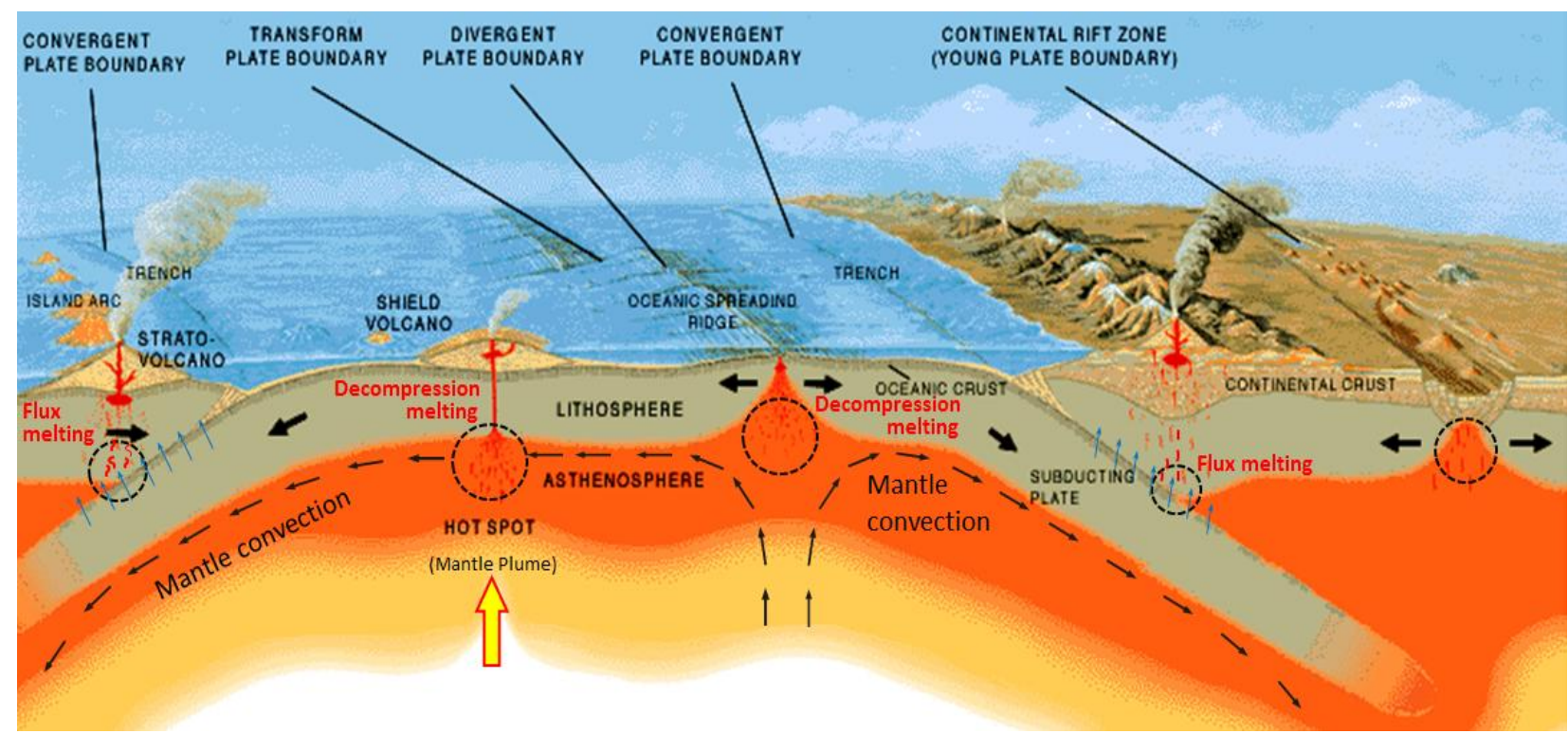

Fig.9. Illustration of formation of magma in the upper mantle (Picture credit: USGS)

3.1.3 Flux Melting. Flux melting occurs when water or carbon dioxide are added to rock. These compounds cause the rock to melt at lower temperatures. This creates magma in places where it originally maintained a solid structure.Much like heat transfer, flux melting also occurs around subduction zones. In this case, water overlying the subducting seafloor would lower the melting temperature of the mantle, generating magma that rises to the surface.

Some common sites of magma formation in the upper mantle is shown in Fig.9.The black circles are regions of partial melting. The blue arrows represent water being transferred from the subducting plates into the overlying mantle.

3.2.Magma Chambers: Magma chamber is the backbone of any volcanic eruptive system. Before I deal with some research papers related to the subject of my paper, it is worthwhile to consider a magma chamber which is an essential part of any volcanic system.

Let us take an example of Yellowstone. As per information from USGS [18], it is underlain by two magma bodies. The shallower one is composed of rhyolite (a high-silica rock type) and stretches from $5 \mathrm{~km}$ to about $17 \mathrm{~km}$ beneath the surface and is about $90 \mathrm{~km}$ long and about $40 \mathrm{~km}$ wide. The chamber is mostly solid, with only about 5 $15 \%$ melt. The deeper reservoir is composed of basalt (a low-silica rick type) and extends from $20 \mathrm{~km}$ to $50 \mathrm{~km}$ beneath the surface. Even though the deeper chamber is about 4.5 times larger than the shallow chamber, it contains only about $2 \%$ melt.

In order to envisage the size of a magma chamber of a volcano of VEI- 8, have a look at Fig.10.It's hard to imagine the massive size and volume, but the following image puts it into some perspective while visualizing the SF Bay Area with Sacramento, San Jose, and the Sierra's in the background. 


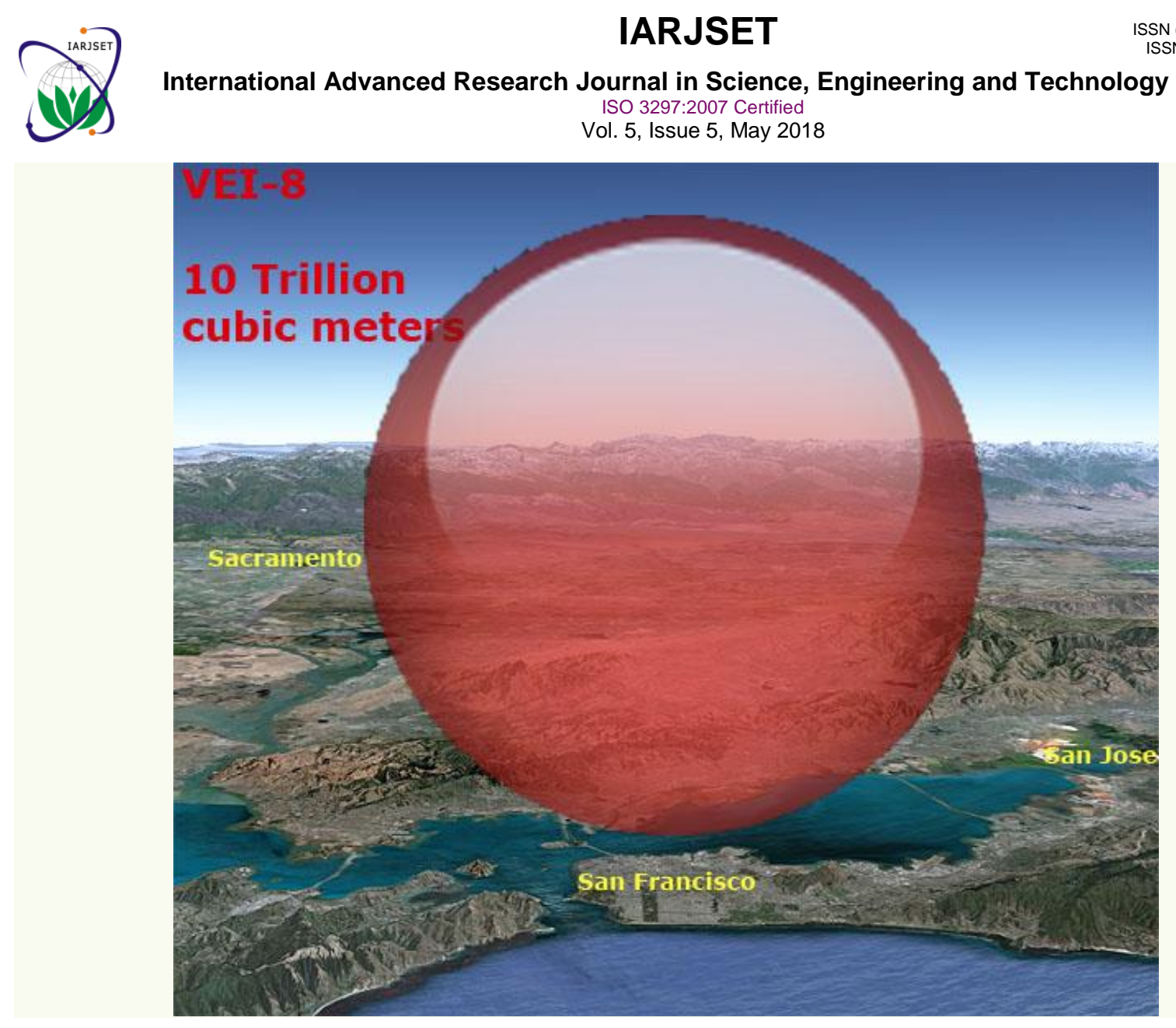

Fig.10 Comparison of size of a Magma Chamber

I have visited United States a number of times and stayed in San Francisco, California for over a decade. The above comparison when related to some place in the city of Mumbai, India can be an area between the Western Ghats and the Arabian Sea in the East-West and Palghar (North Mumbai) and city of Mumbai in the North-South. When a chamber is of this size, one can imagine the size of the reservoir. The approximate volumes of magma chambers of VEI 4 to 8 are shown below:

Volcanic Explosive Index (VEI)

4

5

6

7

8

\section{Volume}

1 Billion cubic meters

10 Billion cubic meters

100 Billion cubic meters

1 Trillion cubic meters

10 Trillion cubic meters

In order to probe Magma Reservoirs to Improve Volcano Forecasts, Jacob B. Lowenstern, Thomas W. Sisson, and Shaul Hurwitz have used Geothermal rigs at Te Mihi, New Zealand (Fig.11) to learn 


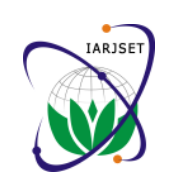

IARJSET

ISSN (Online) 2393-8021 ISSN (Print) 2394-1588

International Advanced Research Journal in Science, Engineering and Technology

ISO 3297:2007 Certified

Vol. 5, Issue 5, May 2018

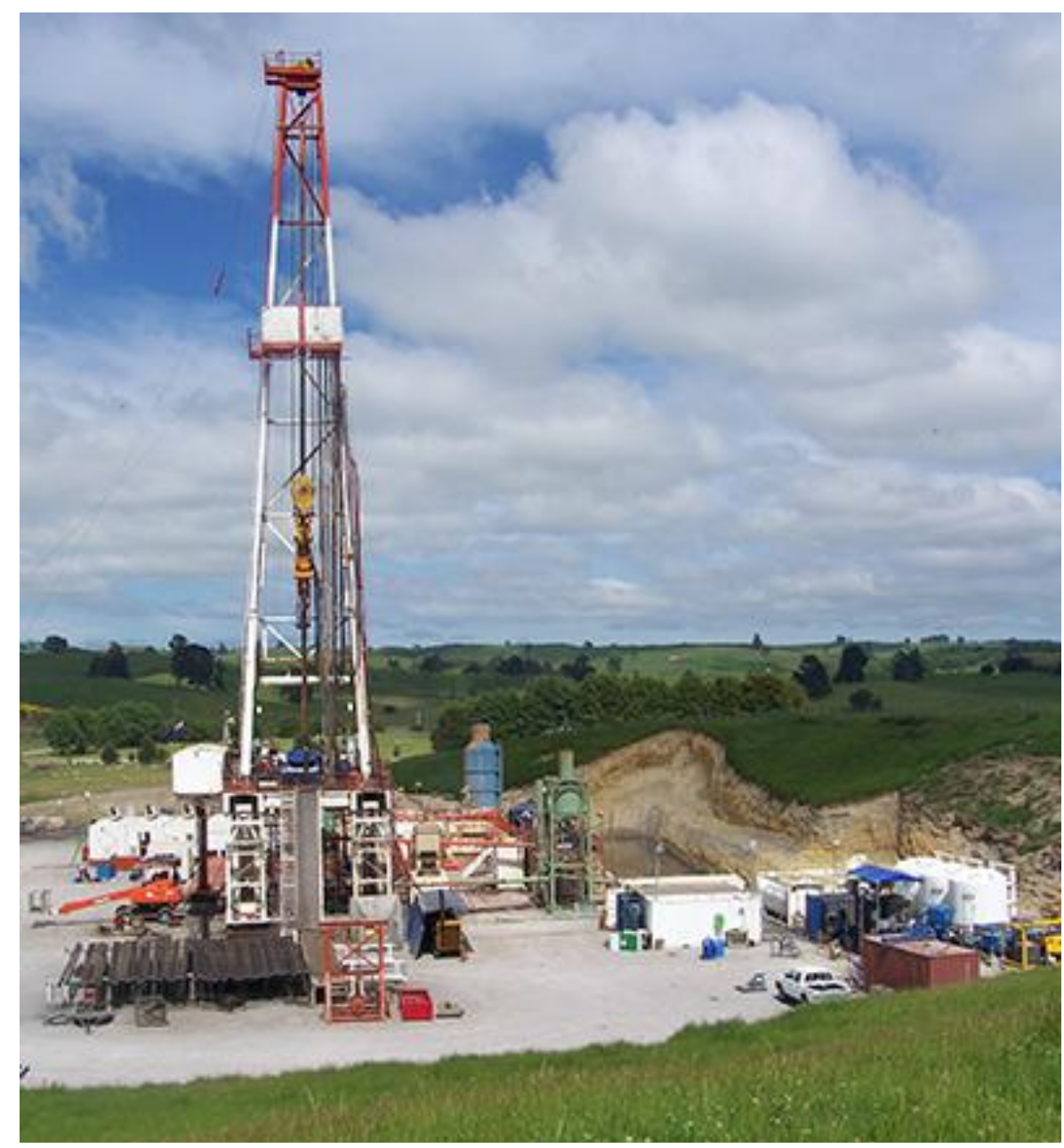

Fig.11 Geothermal drill rig at Te Mihi, New Zealand.

more about magma reservoirs. Geothermal drill holes could be extended, with scientific drilling aimed at probing magmatic environments.

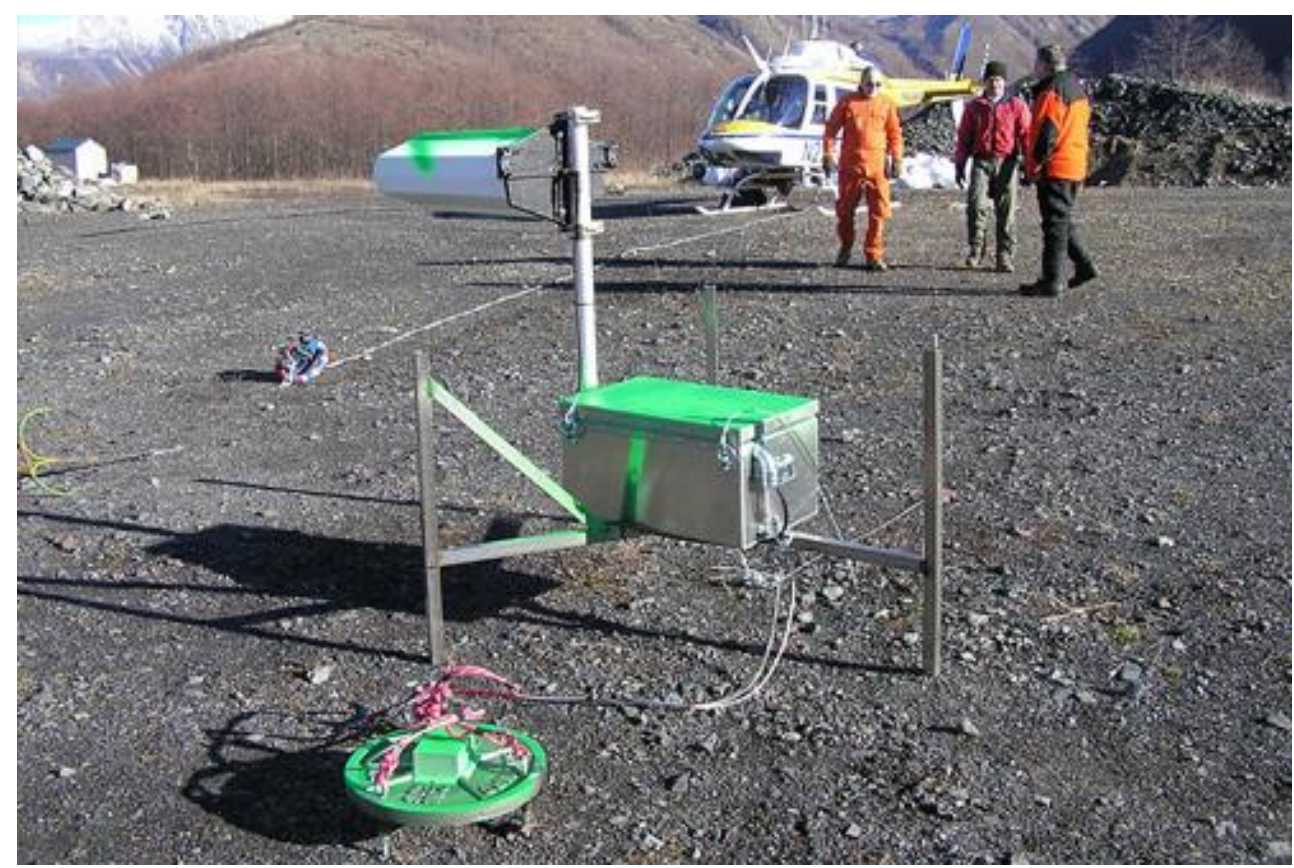

Fig.12 A portable Monitoring Station called “Spider" [18] 


\section{IARJSET

A portable monitoring station called a "spider." (Fig.12) is used to explore the interiors of a volcano. Spiders are dropped into an active volcano's crater and transmit seismic data to geologists about the movement of magma inside. [18]

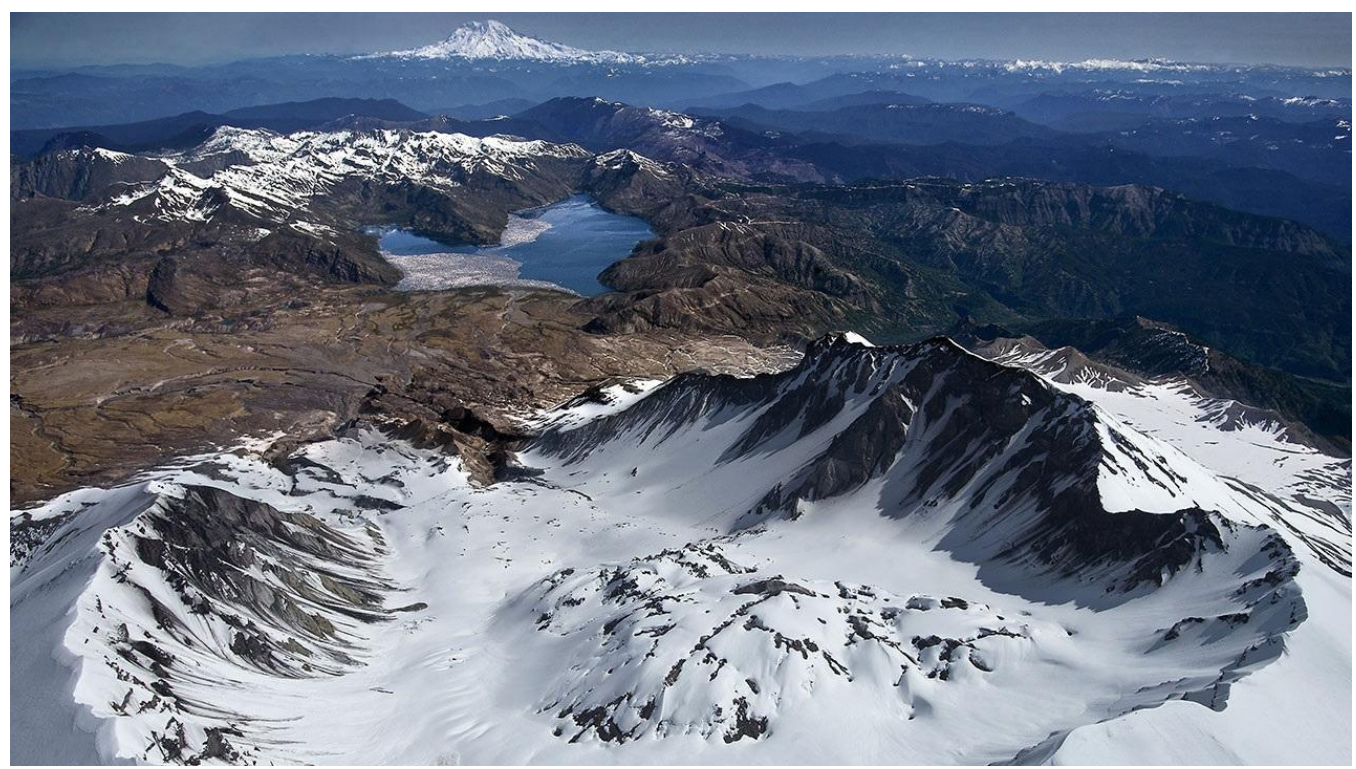

Fig.13 Mount St. Helens with lid blown off in the 1980 eruption (Picture Credit: DEAN J. KOEPFLER/MCT/NEWSCOM)

Eric Hand [4] has reported that "Deep magma chambers seen beneath Mount St. Helens". Geoscientists have for the first time revealed the magma plumbing beneath Mount St. Helens, the most active volcano in the Pacific Northwest. The emerging picture includes a giant magma chamber, between 5 and 12 kilometers below the surface, and a second, even larger one, between 12 and 40 kilometers below the surface. The two chambers appear to be connected in a way that could help explain the sequence of events in the 1980 eruption that blew the lid off Mount St. Helens.(Fig.13). Researchers further say that the huge magma chamber could also explain the recent swarm of earthquakes that shook the town in recent years. Although experts do not expect drastic events or an eruption anytime soon, they say the chamber contains enough magma to fill 80,000 Olympic-sized swimming pools.

Alyssa Navarro [1] has reported of a "Huge Magma Chamber under New Zealand Town with no Volcano to blame for Earthquakes"

Gudmundsson [7] has given an exhaustive treatment on Magma Chambers. The author has extensively dealt with the details of magma chambers mentioning that an existing magma chamber is a necessary condition for the generation of a large volcanic edifice. In the [Fig.14] is shown a schematic illustration of a strato volcano. The magma chamber acts as a sink for magma from a deeper magma accumulation zone (here referred to as reservoir) and a source for the inclined sheets, sills and dykes (including feeder dykes). Many of the dykes become arrested, some becoming deflected into sills. The volcano builds up into a cone because the chamber channels magma to a limited area on the surface.

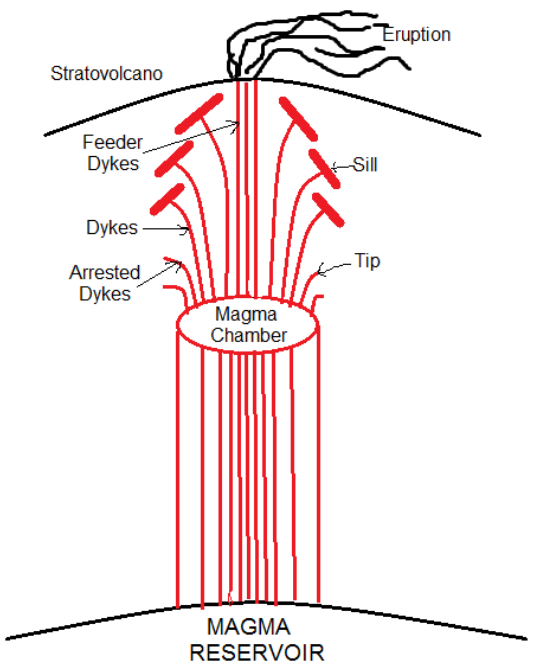

Fig.14 Rudiments of an erupting volcano with Magma Chamber as a thermodynamic system (Figure re-drawn from original) Picture Credit:[7] 


\section{International Advanced Research Journal in Science, Engineering and Technology}

ISO 3297:2007 Certified

Vol. 5, Issue 5, May 2018

Here the magma chamber is the thermodynamic system. The hosting crustal segment, including the volcanic edifice for which the magma chamber is a source (it supplies magma to the volcano) as well as the deeper reservoir, for which the magma chamber acts as a sink (it receives magma from the reservoir), acts as the surroundings to the magma-chamber system. In the present notation, heat received by the magma chamber and work done on the magma chamber (by the surroundings) are regarded as positive.

A schematic diagram of various possible shapes of magma chambers is shown in Fig.15. Fig.(a) is shown a chamber with very irregular boundaries (surfaces). They are thermally and mechanically unstable and tend to smooth out the irregularities. In Fig.(b) the chamber is roughly prolate and elliptical. Such chambers may exist beneath some volcanic edifices particularly and comparitively narrows cones with steep slopes. This follows because the magma chamber ruptures and associated feeding dykes would mostly be injected from the top of the chamber indicating a narrow surface area for the eruptions. In Fig.(c) the chamber is almost spherical and the most common particularly at the later stages of chamber evolution. Many such chambers generate swarms of inclined sheets. In Fig.(d) the chamber is roughly oblate ellipsoidal or sill like chambers are presumably the most common chamber geometry specially at the mid-ocean ridges.
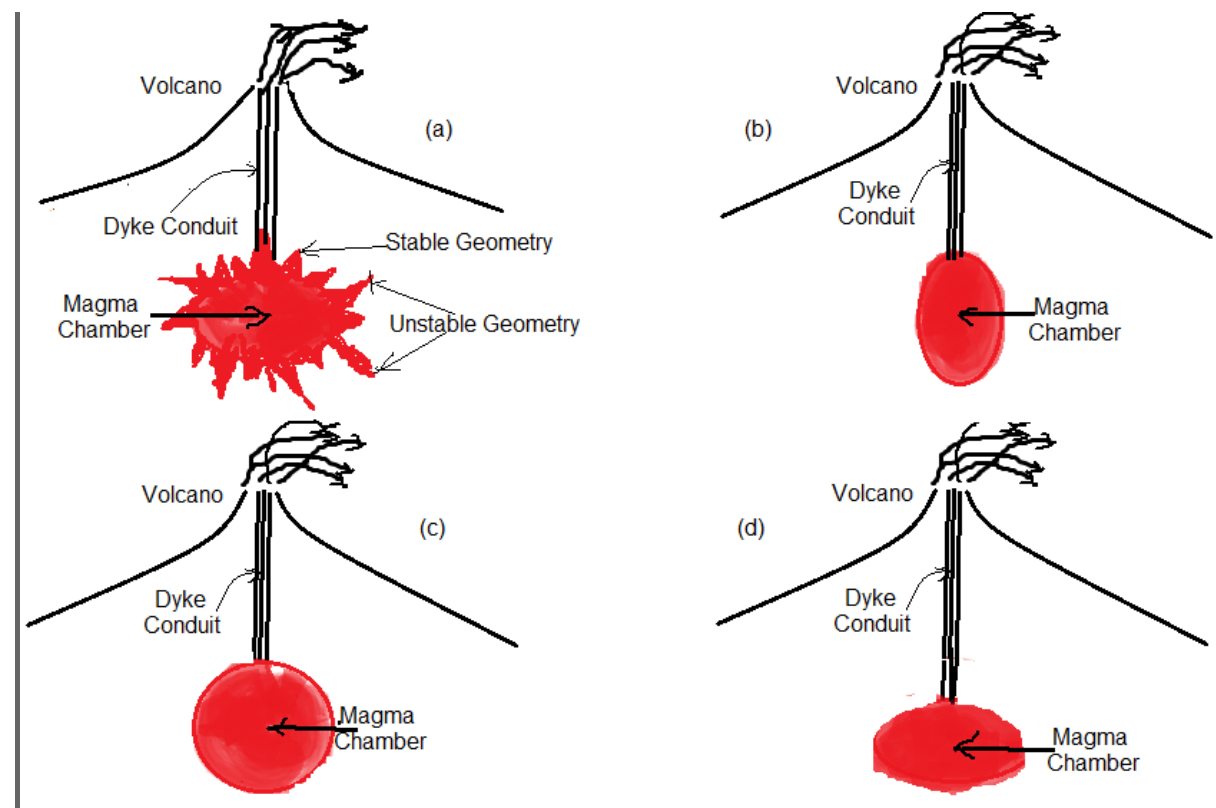

Fig.15 Possible shapes of Magma Chambers (Figure re-drawn from original. Picture Credit:[7]

In(Fig.16) is illustrated a magma chamber formation through the injection sills. In (a) is shown the formation of a sill at the contact between mechanically dissimilar rock layers. In (b) the subsequent dyke injections become arrested and their magma partly absorbed by the original sill. In (c) the sill cluster expands and in (d) forms a sill-like magma chamber that supplies magma to a volcano.
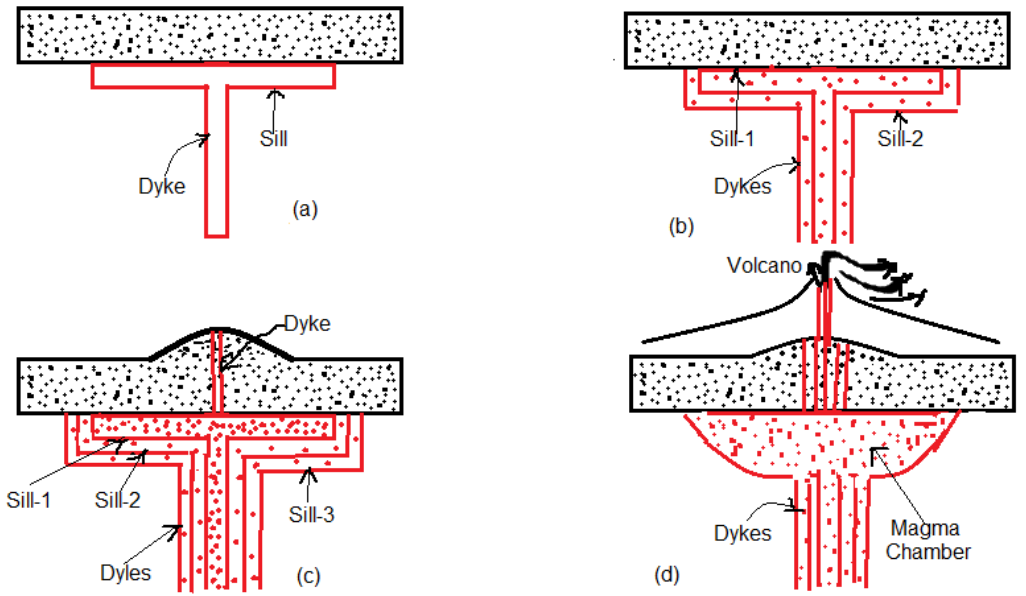

Fig.16 Various stages of Magma Chamber formation.(Figure re-drawn from original. Picture Credit:[7]) 
In Fig. 17 is shown how compartments may be generated through faulting. Flow of magma between compartments 1 $\& 5$ and $2 \& 4$ is unlikely as it has to flow through compartment 3 . However, a minimum flow can be between $1 \& 2$ and $5 \& 4$. In general magma in each compartment has an independent behavior.

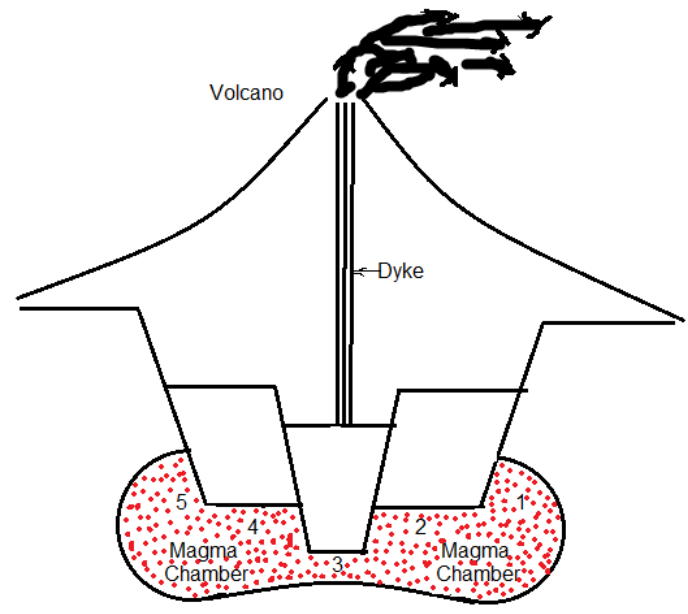

Fig.17 Formation of Compartments in a Magma Chamber .(Figure re-drawn from original. Picture Credit:[7])

In Fig.18is illustrated another possible compartments in a magma chamber. Compartments $1 \& 5$ are of low density magmas whereas $7 \& 11$ are of high density magmas. During typical small eruptions from compartments $1 \& 5$ magma is derived only from the compartment with which the feeder dyke is connected. For larger eruptions magma is drawn from deeper parts of the specific compartments (indicated by the numbers 1a, 2a and 3a) and the associated lowering of the hydraulic potential may eventually result in magma being driven into that compartment from one or more adjacent ones. (for example, driven from compartment 2 to compartment 1 during a comparatively large eruption from compartment 1)

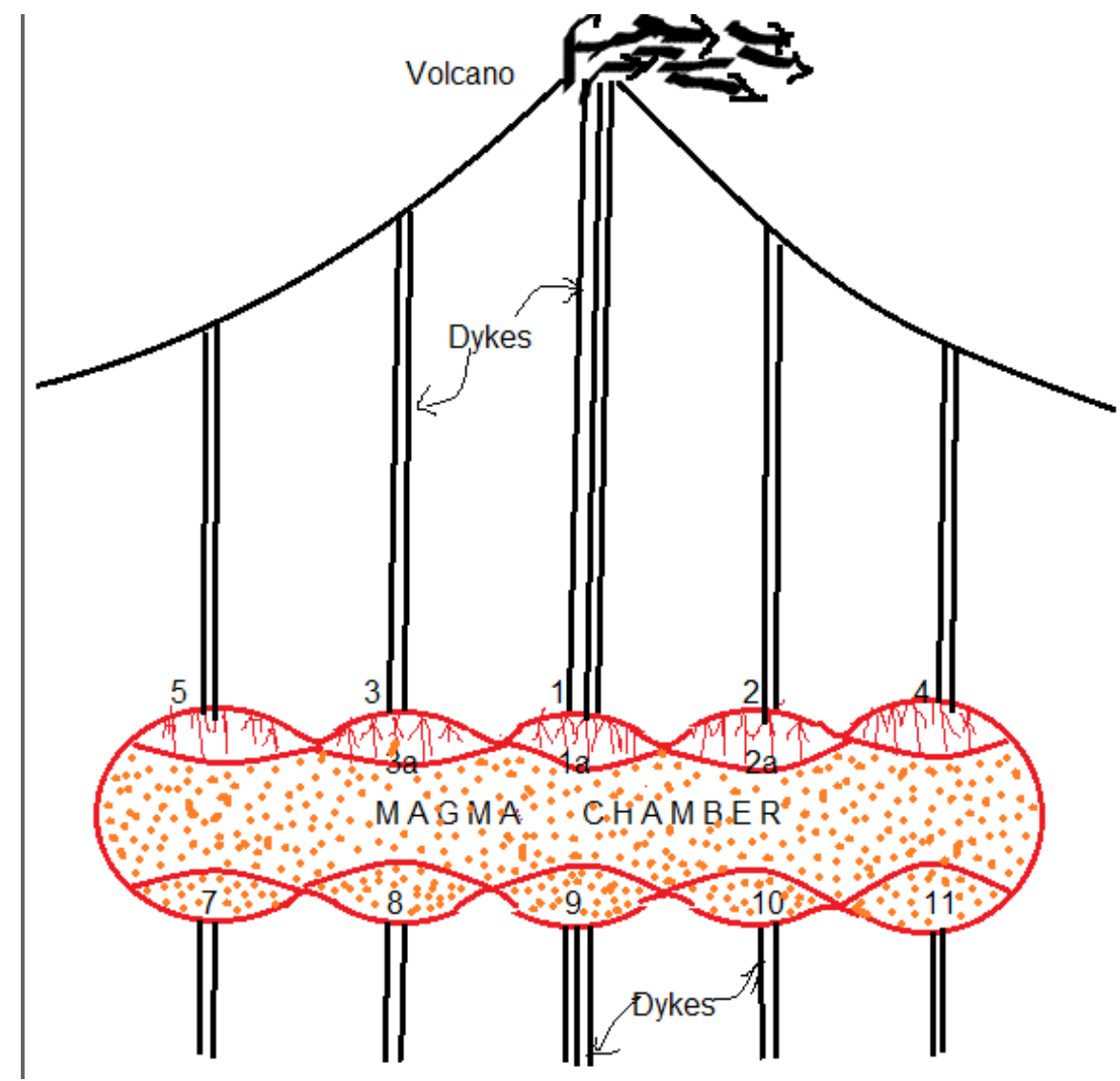

Fig.18. Another possible formation of Compartments..(Figure re-drawn from original. Picture Credit:[7]) 


\section{International Advanced Research Journal in Science, Engineering and Technology}

ISO 3297:2007 Certified

Vol. 5, Issue 5, May 2018

Using Navier-Stokes equation and assuming laminar flow, the author [7] has obtained a formula for the volumetric flow rate $\mathrm{Q}$ of magma through a volcanic fissure as:

$$
\mathrm{Q}=\frac{\Delta \mathrm{u}^{3} \mathrm{~W}}{12 \mu_{\mathrm{m}}}\left[\left(\rho_{r}-\rho_{\mathrm{m}}\right) \mathrm{g} \operatorname{Sin} \alpha-\left(\frac{\partial \mathrm{p}_{e}}{\partial \mathrm{L}}\right)\right]
$$

Where $\Delta \mathrm{u}$ is the opening or aperture of the feeder dyke or volcanic fissure, W is the length or strike dimension of the feeder- dyke (the volcanic fissure) at the surface, $\mu_{\mathrm{m}}$ the dynamic (absolute) viscosity (including the volcano) through which the dyke propagated to the surface, $\mathrm{g}$ is the acceleration due to gravity. $\alpha$ is the dip of the feeder-dyke and $\left(\frac{\partial \mathrm{p}_{e}}{\partial \mathrm{L}}\right)$ is the vertical excess pressure gradient in the direction of the dip dimension of the dyke $\mathrm{L}$

The total volume, $\mathrm{V}$ that flows out of the pyroclastic magma chamber through the feeder- dyke before the eruption comes to an end has been estimated by the author [7] by the following formula:

$$
V=f p_{e}\left(\beta_{p}+\beta_{m}\right) V_{c}
$$

where $\mathrm{f}$ is the porosity (magma fraction) of the chamber, $\mathrm{p}$ is the magma excess pressure in the chamber before rupture and feeder-dyke formation, $\beta_{\mathrm{m}}$ is the magma compressibility and $\beta_{\mathrm{p}}$ is the pore compressibility of the magma chamber and $V_{c}$ is the total volume of the chamber.

Following "Cause and Effect" formalism the cause for eruption is intrusion of magma to the magma chamber from the reservoir. The size of the reservoir is so large that any stray intrusion of magma to the reservoir from the upper mantle will only add to the quantity of magma in it and will not have any effect related to eruption. It will be something like a frog entering a large well.

\section{PLATE TECTONIC THEORY OF VOLCANOES}

4.0 Plate Tectonic Theory (Cause of Volcanoes):- Tilling Robert I [16] Cause of volcanoes can be explained on the basis of Plate Tectonic Theory which is a generally acceptable by geologists and specially volcanologists. According to this theory, the surface of the earth is broken into a number of shifting slabs or plates which average about 50 miles in thickness. These plates move relative to each other above a hotter, deeper, more mobile zone at an average rate of few inches per year. Most of the world's active volcanoes are located along or near the boundary between shifting plates and are called "Plate boundary volcanoes". In the plate tectonics, there are two aspects. (i) Divergent plate boundary and (ii) Convergent plate boundary.

4.1 Divergent plate boundary:- Two tectonic plates diverge from one another at the mid-oceanic ridges. Due to the cooling and solidifying of the molten rock, new oceanic crust is formed. Due to the pull exerted by the tectonic plates, the crust becomes very thin at the mid-oceanic ridges. The thinning of crust creates a pressure leading to an adiabatic expansion and partial melting of the mantle thus causing 'volcanism'. Most divergent boundaries lie at the bottom of the ocean and hence most volcanic activity is submarine, forming new sea floor. This is certainly a great boon by almighty by freeing humans of the danger from many volcanoes. Black smokers or deep sea vents are examples of this kind of volcanic activity. When the mid-oceanic ridge is above sea level, volcanic islands are formed, for example, Iceland is a volcanic island.

4.2 Convergent Plate boundaries:- When an oceanic plate and a continental plate collide, subduction zones are formed. That is the oceanic plate subducts or submerges under the continental plate forming a deep ocean trench just offshore. The melting temperature of mantle wedge decreased due to water released from the subducting plate thus creating magma which is highly viscous because of the silica content. Many times it is cooled at depth, but when it reaches the surface, a volcano is formed. Example of such a volcano is the Mount Etna and all the volcanoes in the Pacific Ring of Fire. (Fig.20) 
In the following Fig.19 is shown Plate tectonics, Convergent and Divergent boundaries.

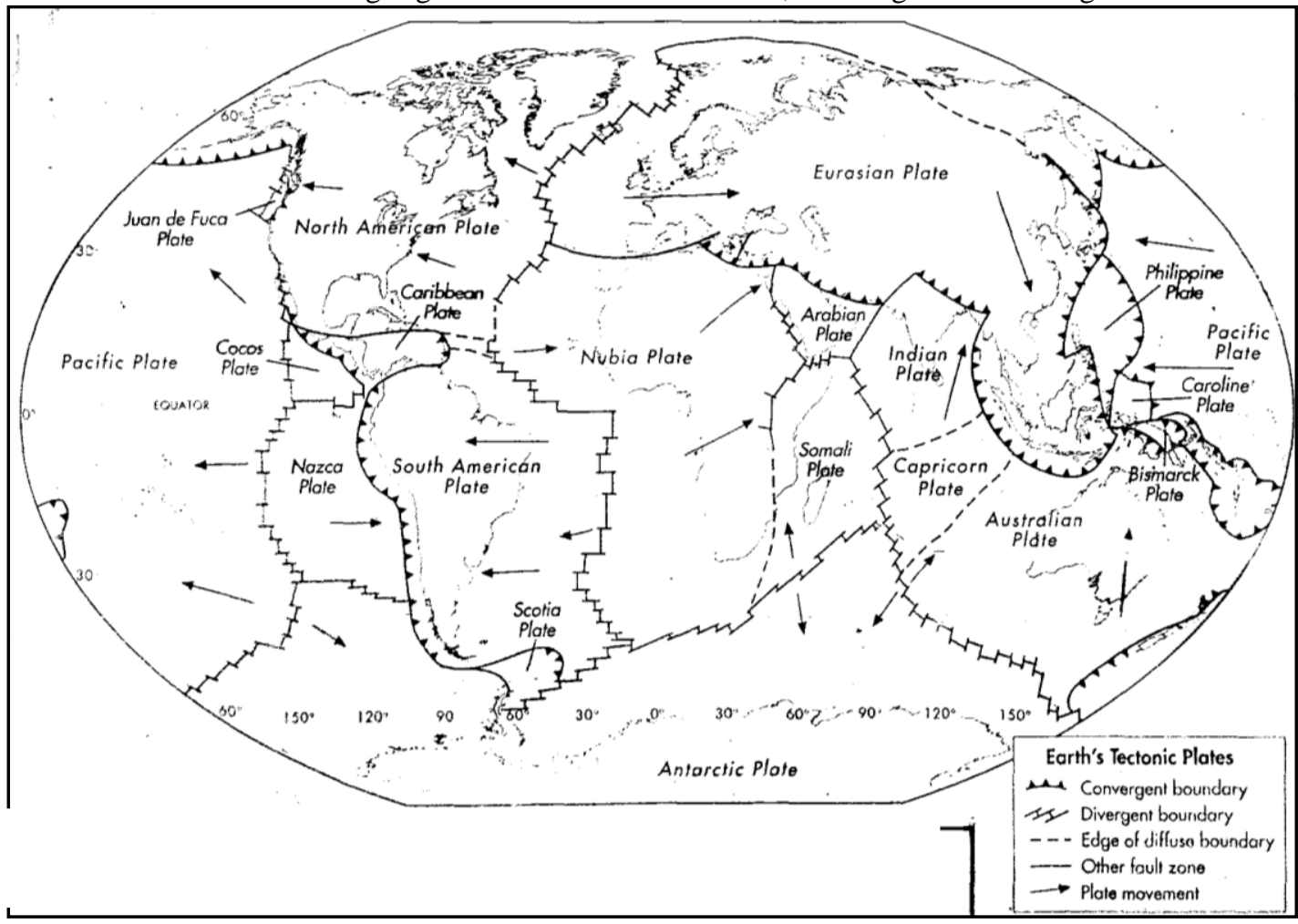

Fig.19.Earth's Tectonic Plates [10]

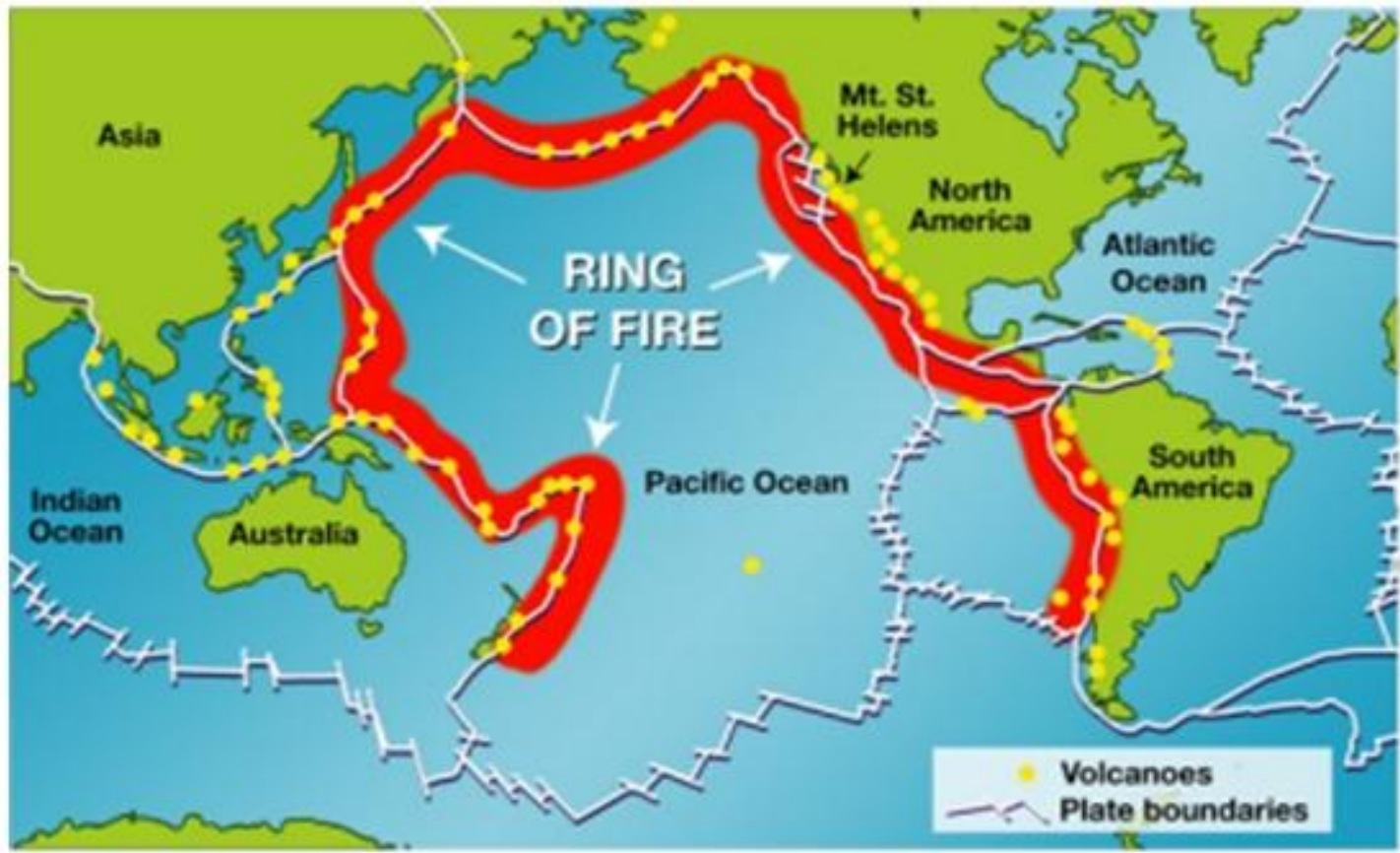

Fig.20 The Pacific Ring of Fire

4.3 Hot Spots:- There are some volcanic provinces postulated to be formed by mantle plumes. They are called "Hot Spots". Large columns of hot material rise from the core-mantle boundary. As the tectonic plates move across them, each volcano becomes dormant after a while and a new volcano is formed as the plate gets further shifted. The Hawaiian islands have been formed in this manner and also the Snake River Plain with the Yellowstone Caldera being the part of North American Plate currently above the Hot Spot. 


\section{International Advanced Research Journal in Science, Engineering and Technology}

ISO 3297:2007 Certified

Vol. 5, Issue 5, May 2018

\section{MAGMA WAGGING}

5.0 What adds to the beauty of any eruption is the wagging of magma when it comes out of the vent. Hence, it is worthwhile to discuss a Research Paper by two stalwarts, A. Mark Jellinek and David Bercovici, [12].

The authors start by mentioning that "A Volcanic Tremor is an ubiquitous feature of any erupting volcano". What is of importance is the behavior of magma column in the conduit. They have considered a simplified version of the model in which the annulus of diameter, $\mathrm{u}$ (Fig.21) contains a compressible but impermeable gas-magma foam of disconnected bubbles that rises

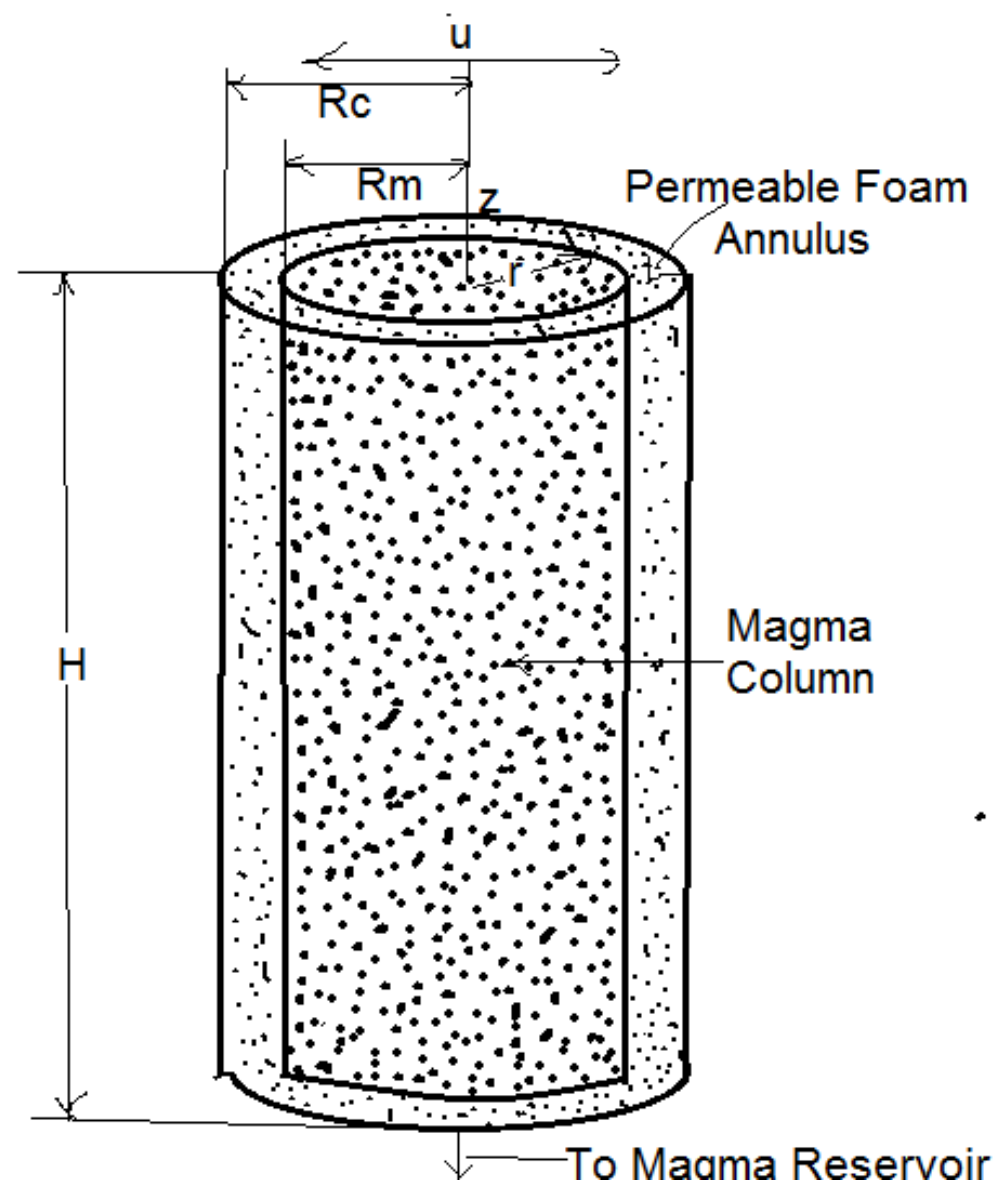

Fig.21 Sketch (re-drawn from original) of the Magma Wagging model of Volcanic tremor (Picture credit: [12]

with the magma column. The behavior of a column of very viscous magma surrounded by a foam-spring of fixed mass is similar to an unforced damped harmonic oscillator. The primary model prediction for the volcanic tremor is the frequency of wagging magma. The equations to obtain the frequency are non-linear and hence trivial. The authors, David Bercovici, et.al. have systematically derived and obtained the angular frequency, $\omega_{0}$ for the magma wagging as

$\omega_{0}=\sqrt{[}\left[\frac{2 \rho_{0} c^{2}}{\varphi_{0} \rho_{m}\left(R_{c}^{2}-R_{m}^{2}\right)}\right]$

where the linear frequency is $\frac{\omega_{0}}{2 \pi}$, $c$ is the speed of sound in gas given by $c==\sqrt{ }\left(\frac{R T}{m_{g}}\right)$ where $R$ is the universal gas constant, $\mathrm{T}$ the absolute temperature lying between 1000 and 1300 degree Kelvin and $\mathrm{m}_{\mathrm{g}}$,

the molar mass of water which is the dominant volatile in the erupting gas and its value is $18 \times 10^{-3} \frac{\mathrm{kg}}{\mathrm{mol}}$. The value of $\mathrm{c}$ is found to be about $700 \frac{\mathrm{m}}{\mathrm{s}}$. $\rho_{0}$ and $\varphi_{0}$ are the density and volume fraction of the undisturbed gas in the annulus, The volume fraction is the porosity equal to $0.7 . \rho_{\mathrm{m}}$ the magma density, $\mathrm{R}_{\mathrm{c}} \mathrm{andR}_{\mathrm{m}}$ are the radii of the conduit and magma column respectively. 


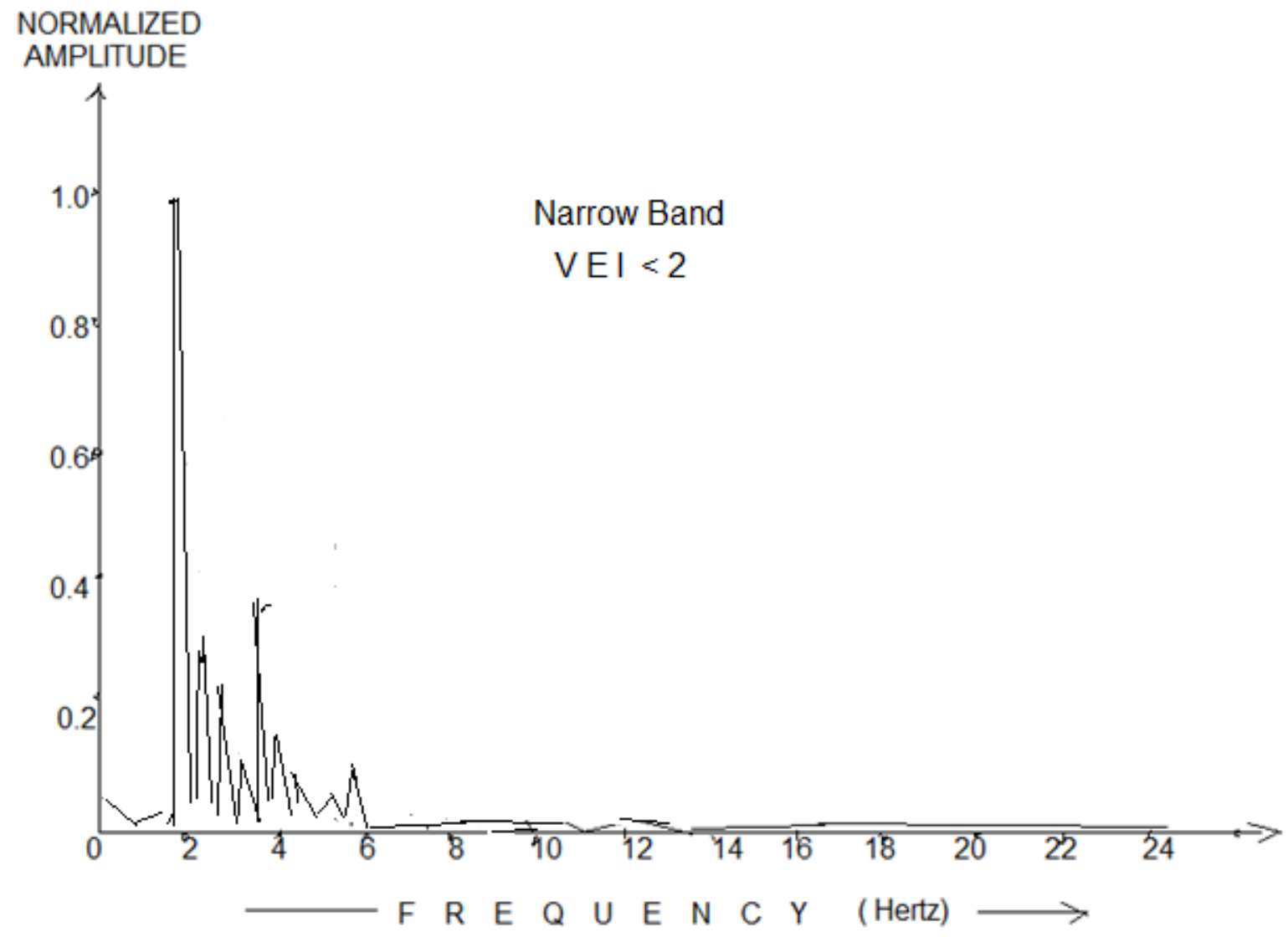

Fig.22 The frequency distribution for VEI < 2 (Narrow Band)(Graph re-drawn by author: Graph Credit:[12])

The frequency distribution for the 1998 eruption of White Island New Zealand volcano is shown in Fig.22 for VEI < 2 (Narrow Band) and in Fig.23 for VEI $=3$ for the Broad Band. The narrow band lies between 0.5 to $2 \mathrm{H}_{\mathrm{z}}$ and the broad band can climb from 2 to $7 \mathrm{H}_{\mathrm{z}}$.

It is found that oscillations persist longer for taller columns. The critical height, $\mathrm{H}_{\mathrm{c}}$ required for wagging, however, is

$\mathrm{H}_{\mathrm{c}}=\frac{\pi}{2}\left[\sqrt{\left(\frac{\mu_{m}}{2 \rho_{\mathrm{m}} \omega_{0}}\right)}\right]$

where $\mu_{\mathrm{m}}$ is the magma viscosity. This, on substitution of values, is found to be 40 meter. A typical $\mathrm{H}$ is about $1 \mathrm{~km}$. From the above equation (4), the longest dimensional damping time, $t$ is given by

$$
\mathrm{t}=\left(\frac{2 \mathrm{H}}{\pi}\right)^{2}\left(\frac{2 \rho_{m}}{\mu_{\mathrm{m}}}\right) .
$$

For a column of height $1 \mathrm{~km}, \rho_{\mathrm{m}}=2500 \frac{\mathrm{kg}}{\mathrm{m}^{3}}$, and taking minimum value of viscosity $10^{5} \mathrm{~Pa} \mathrm{~s}$, we get the damping time as

$$
\begin{aligned}
& \left(\frac{2 \times 1000}{3.142}\right)^{2}\left(\frac{2 \times 2500}{10^{5}}\right)=\left(\frac{2000}{3.142}\right)^{2}\left(5 \times 10^{3} \times 10^{-5}\right)=(636.54)^{2} \times 5 \times 10^{-2}=405183 \times 0.05 \\
& =20259 \text { second }=\frac{20259}{3600}=5.63 \text { hours }
\end{aligned}
$$

which is slightly less than 6 hours 


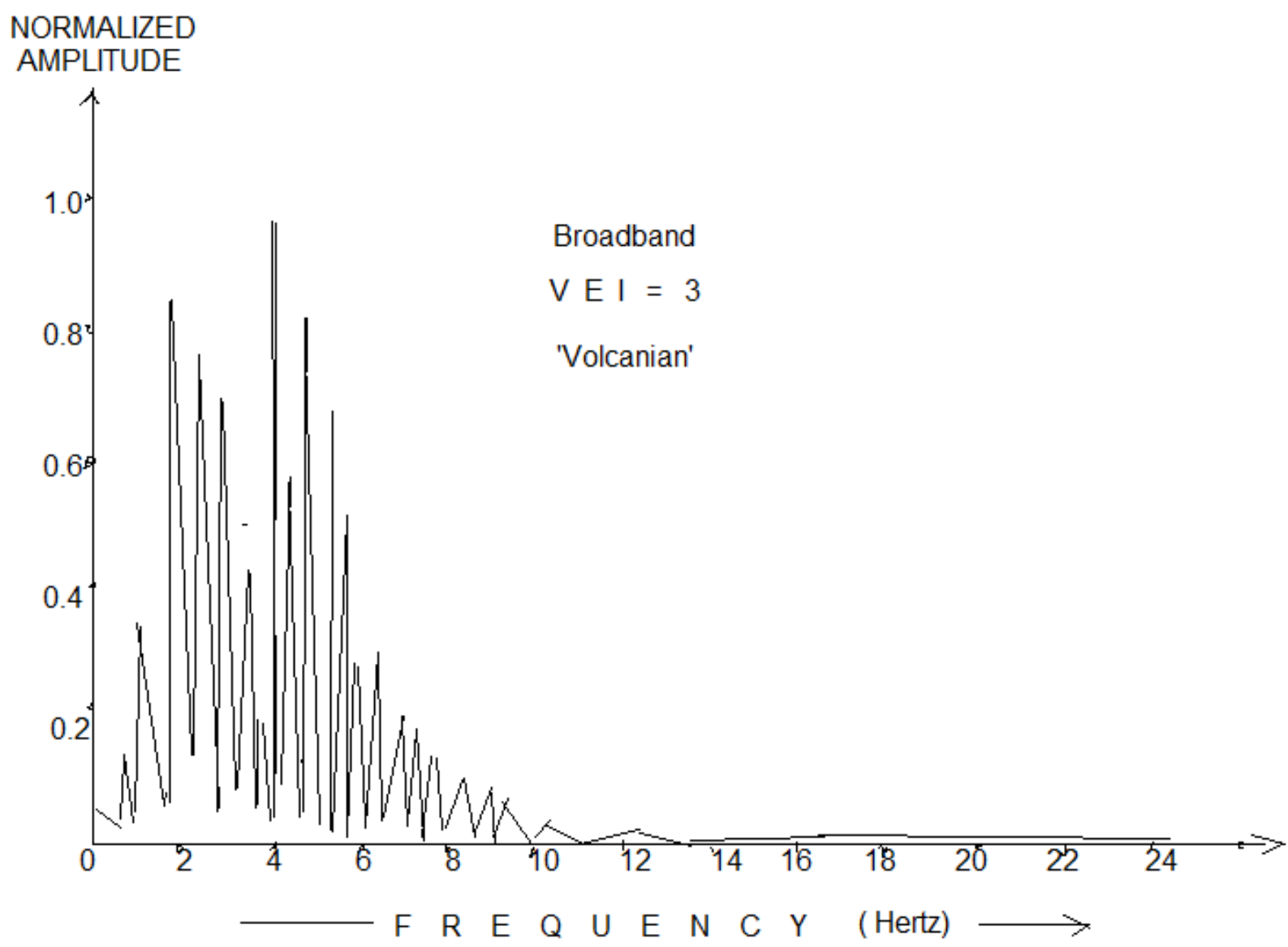

Fig.23 The frequency distribution for VEI = 3 (Broad Band) (Graph re-drawn by author: Graph Credit:[12])

Now, however, when the viscosity is increased by 10 units, say from $10^{5}$ to $10^{6} \mathrm{~Pa}$ s, then the damping time will be 2025.9 second $=\frac{2025.9}{3600}=0.563$ hour $=34$ minutes which is slightly more than $\frac{1}{2}$ hour. As the viscosity term appears in the denominator in the formula for the damping time, the more the viscosity the less will be the damping time. As viscosity decreases with increase of temperature, the magma coming out of the vent gets cooled when in contact with the previously cooled lava and the atmospheric air thereby increasing its viscosity.

5.1 The Exit Velocity: Authors, Turcotte D.L and et.al have obtained a formula for the exit velocity, u given by

$$
\mathrm{u}=\left(\varphi_{0} \mathrm{RT}_{0}\right)^{\frac{1}{2}} \ln \left(\frac{\mathrm{p}_{0}}{\mathrm{p}}\right)
$$

where $\varphi_{0}$ is the original mass fraction of the dissolved vapor, $\mathrm{R}$ the gas constant for the vapor, $\mathrm{T}_{0}$ the constant temperature and $\frac{\mathrm{p}_{0}}{\mathrm{p}}$ the pressure ratio across the expansion. With $\varphi_{0}=1$ per cent, $\mathrm{T}_{0}=1000 \mathrm{~K}$ and $\frac{\mathrm{p}_{0}}{\mathrm{p}}=100$, they found $\mathrm{u}=300 \frac{\mathrm{m}}{\mathrm{s}}$ consistent with observations for volcanic eruptions.

\section{VOLCANIC ERUPTION PRECURSORS}

6.0GlynWilliam-Jones and Hazel Rymer [6] have dealt with detection of volcanic eruption precursors by using gravity and deformation measurements. They have

dealt with the so-called Mogi model by studying the Physics of the behavior of magma in a magma chamber wherein a fresh magma happens to enter the chamber creating ground (crustal) deformation, $\Delta \mathrm{h}$ combined with gravity deformation, $\Delta \mathrm{g}$. The degree of interaction between the intruding magma and the pre-existing magma in the chamber will determine the nature and rate of eruption and the same is really a complicated procedure for both the physicists and chemists. The microgravity surveys and deformation measurements are carried out at a network of stations in and around the active crator. The authors have carried out their investigations within a radius of about $6 \mathrm{~km}$ from the crator. The magma chamber is assumed to be spherical and if it lies at a considerable depth, as is usually the case, it can be treated as a point source. In Fig. 24 is illustrated the procedural aspect of measurement. The ground deformations 


\section{International Advanced Research Journal in Science, Engineering and Technology}

ISO 3297:2007 Certified

Vol. 5, Issue 5, May 2018

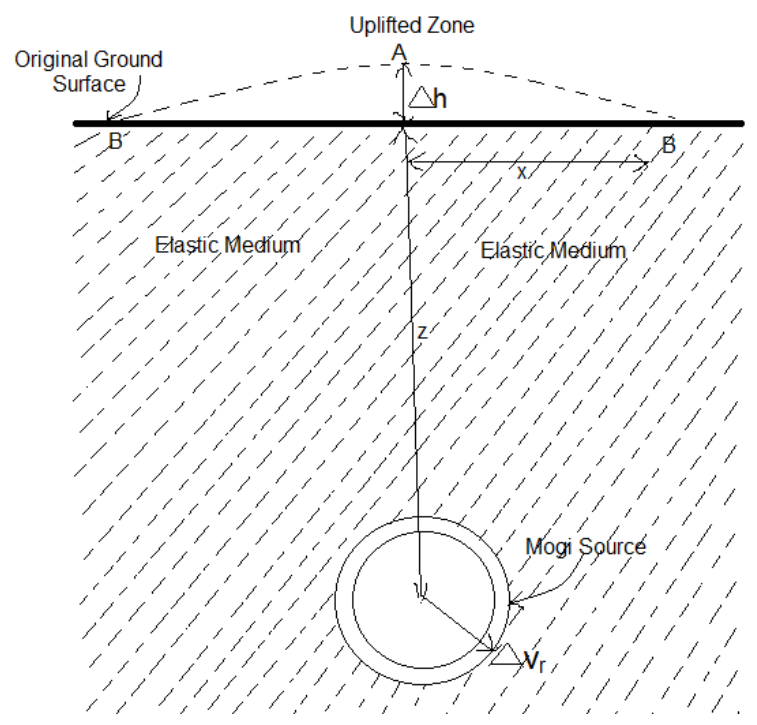

Fig.24 Model of a Mogi type magma reservoir

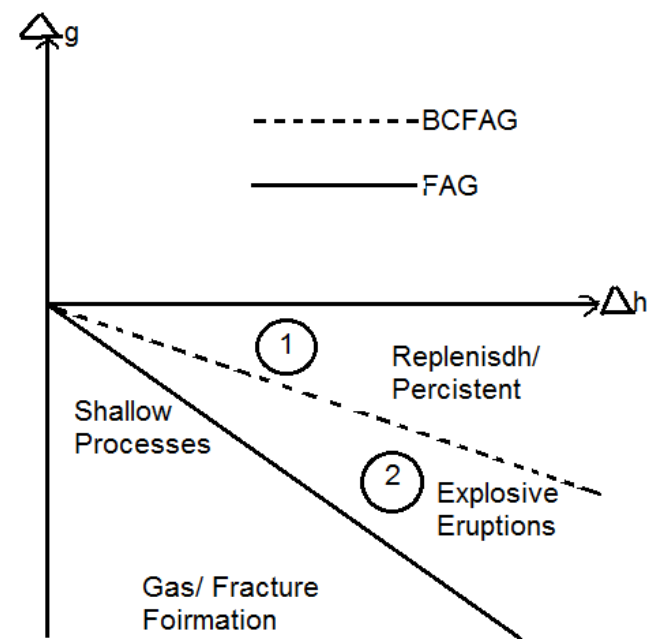

Fig.25Illustration of trigger mechanism for

Picture re-drawn by author Picture Credit: [6] Explosive eruptions. Picture re-drawn by author. Graph Credit: [6]

can be measured using techniques such as Global Positioning System (GPS). The system uses satellites in space and if there is some error in the measurement, a Differential Global Positioning System (DGPS) which can detect small off axis variations few kilometers from the active region (zone B) A remote sensing technique known as Synthetic Aperture Radar differential Interferometry (DInSAR) ( Fig.26) is also used. In this method two radar images are taken at two different times. Radio waves are bounced off the crustal surface on two different passes, Pass- 1 and Pass- 2 . Phase difference resolve elevation changes in fraction of wavelength. Crustal deformation can be detected from the difference in the images. DInSAR is an advantageous method and surveyors like it as it can be operated in hazardous areas also. The ground tilt such as at region $\mathrm{A}$ can be measured by tiltmeters. The change in edifice volume, $\Delta \mathrm{V}_{\mathrm{e}}$ of the volcano can be estimated by integrating the observed height changes over the area of deformation. With the help of the elastic properties of the country rock and with the amount of crustal deformation, one can estimate the change in volume, $\Delta \mathrm{V}_{\mathrm{r}}$ of the sub-surface magma reservoir. The changes in sub-surface magma mass $\Delta \mathrm{M}_{\mathrm{m}}$ can be quantified on monitoring the variations in acceleration due to gravity at regions such as A and B. (Fig.24). If there is no change in density $\rho$ of magma in the reservoir, the amount by which gravity varies with elevation can be described by the Bouguer-Corrected Free Air Gradient (BCFAG) of a spherical body and is given by a formula:

$$
(\mathrm{BCFAG})_{\text {spherical }}=(\mathrm{FAG})+\left(\frac{4 \pi G \times 10^{8}}{3}\right) \rho \ldots \ldots \ldots \ldots \ldots \ldots \ldots \text { ( 7) }
$$

where $G$ in italics is the universal constant of gravitation the value of which is $6.67 \times 10^{-11} \mathrm{Nm}^{2} \mathrm{~kg}^{-2}$ and $\rho$ the magma density. The theoretical value for FAG is $-308.6 \mu \mathrm{Galm}^{-1 *}$. Terrain effects and Bouguer anomalies can cause this value by $40 \%$

*This unit, Gal is named after the Italian physicist, mathematician and astronomer Galileo (1564-1642).The conversions are as follows: The acceleration due to gravity is $\mathrm{g}=9.8 \mathrm{~ms}^{-2} \approx 10 \mathrm{~ms}^{-2}$.

$1 \mathrm{Gal} \approx 0.001 \mathrm{~g} \approx 10^{-2} \mathrm{~ms}^{-2} \therefore 1 \mu \mathrm{Gal} \approx 10^{-8} \mathrm{~ms}^{-2}$

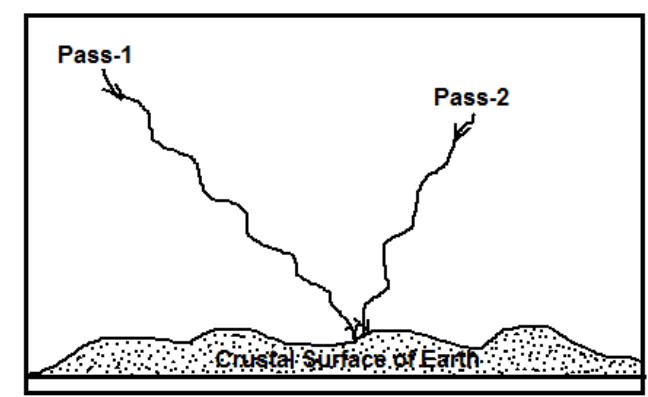

Fig.26 Illustration of the principle of DInSAR 
The situation of inflation is illustrated in Fig.25 During the periods of inflation the increase in elevation ( $\Delta \mathrm{h})$ is accompanied by decreasing gravity $(-\Delta \mathrm{g})$ defined by the BCFAG. The region 1 represents anomalously large gravity increases and may be interpreted in terms of magma intrusion into a magma reservoir resulting in an increase in average density of the reservoir. The region 2 reflects an overall density decrease and mass increase that may be interpreted in terms of gas build up within the magma reservoir which is an important trigger mechanism for explosive eruptions. Data falling below FAG and close to the $\Delta \mathrm{g}$ line may reflect shallow processes as magma and gas fluctuations within the feeder conduit.

The total observed gravity change, $\Delta \mathrm{g}(\mu \mathrm{Gal})$ can be calculated from the following relationship:

$\Delta \mathrm{g}=\left[\frac{\Delta \mathrm{M}_{\mathrm{m}} G \mathrm{z}}{\left(\mathrm{x}^{2}+\mathrm{z}^{2}\right)^{\frac{3}{2}}}\right] 10^{8}$

where $\Delta \mathrm{M}_{\mathrm{m}}$ is the change in sub-surface magma mass, $G$ the universal constant of gravitation, $\mathrm{x}$ is the surface distance in meters from the Mogi source and $\mathrm{z}$ is the depth in meters to the Mogi source (Fig.24) Now, for carrying out a calculation, take magma mass changes of $10^{11} \mathrm{~kg}$, depth between 2 and $6 \mathrm{~km}$, gravity variations greater than $20 \mu \mathrm{Gal}$ measured at a horizontal distance of up to about $4 \mathrm{~km}$. For a mass change of the order of $10^{12} \mathrm{~kg}$ in a reservoir between 2 and $7 \mathrm{~km}$ deep, gravity changes are found to be detectable up to a distance of about $10 \mathrm{~km}$.

6.1 Magma Reservoir Modeling: The situation in the reservoir will depend upon the type of physical state of the intruding magma. What is meant by the type of physical state is whether the intruding magma is of laminar flow with low Reynolds number or of turbulent flow with high Reynolds number. The two situations are shown in Fig.27 a Model (1) and b Model (2) respectively. The Model (1) depicts the intrusion of a laminar flow magma with low Reynolds number. There will be little or no interaction with the surrounding magma in the reservoir. The observed $\Delta \mathrm{g} / \Delta \mathrm{h}$ gradient will fall into region 1 of Fig. 25 . That is, between $\Delta$ hand the BCFAG line. Assuming identical situations, the Model 2 represents intrusion of a turbulent magma with high Reynolds number. The intruding magma will interact vigorously with the magma in the reservoir. The reservoir undergoes a variety of physical changes such as heating, convection, vesiculation and expansion. $\Delta \mathrm{g} / \Delta \mathrm{h}$ gradient in this case will fall into region 2 Fig. 25. That is between the BCFAG and FAG line. There is vigorous mixing and mingling of magma which creates significant bubble formation and the resulting increase in gas pressure within the reservoir is an essential pre-requisite for explosive eruptions. The application of these models to hazard warning is therefore

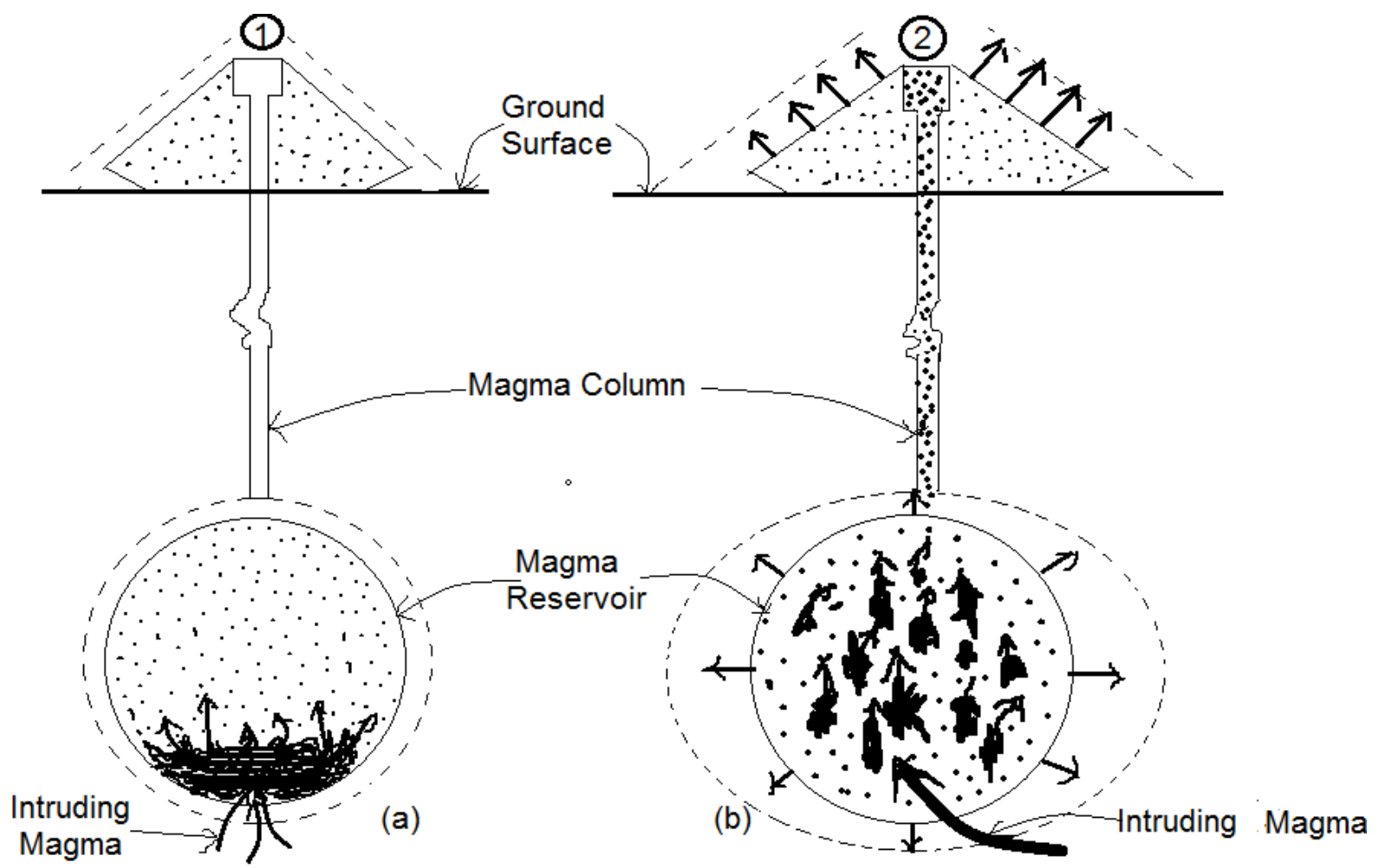

Fig.27 Intrusion of Magma into Magma Reservoir

(a) Model 1. Intruding magma of low Reynolds Number (b) Model 2. Intruding magma of high Reynolds Number 


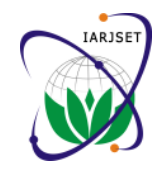

\section{IARJSET \\ International Advanced Research Journal in Science, Engineering and Technology \\ ISO 3297:2007 Certified \\ Vol. 5, Issue 5, May 2018}

that region 1 is a safe region and when the gradient crosses the BCFAG line, the density of magma in the reservoir decreases below any previous value and the system becomes unstable. It is at this stage that the magma will be able to rise and create an eruption hazard. If there is some excess heating, which always is the case, the gas pressure increases and the likelihood of an explosive eruption will be certain.

Prediction by Poisson Statistics: The real life Math[14] has given some literature regarding the probability of eruption. The question is, how can we predict the probability of a volcanic eruption? The easiest model to use, if we already have an estimated probability of eruption is the Poisson distribution:

$f(k ; \lambda)=\operatorname{Pr}(X=k)=\frac{\lambda^{k} e^{-\lambda}}{k !}$,

This formula calculates the probability that $X$ equals a given value of $k$. $\lambda$ is the mean of the distribution. If $X$ represents the number of volcanic eruptions we have $\operatorname{Pr}(X \geq 1)=1-\operatorname{Pr}(x=0)$. This gives us a formula for working out the probability of an eruption as $1-\mathrm{e}^{-\lambda}$. For example, the Yellowstone super volcano erupts around every 600,000 years. Therefore if $\lambda$ is the number of eruptions every year, we have $\lambda=1 / 600,000 \approx 0.00000167$ and $1-\mathrm{e}^{-\lambda}$ also $\approx$ 0.00000167 . This gets more interesting if we then look at the probability over a range of years. We can do this by modifying the formula for probability as

$1-\mathrm{e}^{\mathrm{t} t \lambda}$ where $\mathrm{t}$ is the number of years for our range.

So the probability of a Yellowstone eruption in the next 1000 years is $1-\mathrm{e}^{-0.00167} \approx 0.00166$, and the probability in the next 10,000 years is $1-\mathrm{e}^{-0.0167} \approx 0.0164$. So we have approximately a $2 \%$ chance of this eruption in the next 10,000 years.

A far smaller volcano, like Katla in Iceland has erupted 16 times in the past 1100 years - giving a average eruption every $\approx 70$ years. This gives $\lambda=1 / 70 \approx 0.014$. So we can expect this to erupt in the next 10 years with probability 1 - $\mathrm{e}^{-}$ $0.14 \approx 0.0139$. And in the next 30 years with probability $1-\mathrm{e}^{-0.42} \approx 0.34$.

The models for volcanic eruptions can get a lot more complicated - especially as we often don't know the accurate data to give us an estimate for the $\lambda$. $\lambda$ can be estimated using a technique called Maximum Likelihood Estimation

\section{CONCLUSION}

Even without considering the volcano hazards and prevention, the research paper has run into pages. A volcano is certainly an excellent indicator of heat within the Earth. After the formation of Earth from the Big Bang various physical processes such as volcanoes, earthquakes, tsunamis, clouds and the tides continue unabated till today. At this juncture of conclusion, I would like to quote the famous English geologist and author of the Principles of Geology, Sir Charles Lyell (1797-1875) (Fig.28) [10] who advocated not only uniformitarianism but also gradualism. As he put it: "Earth's history is the result of an uninterrupted succession of physical events governed by the laws now in operation"

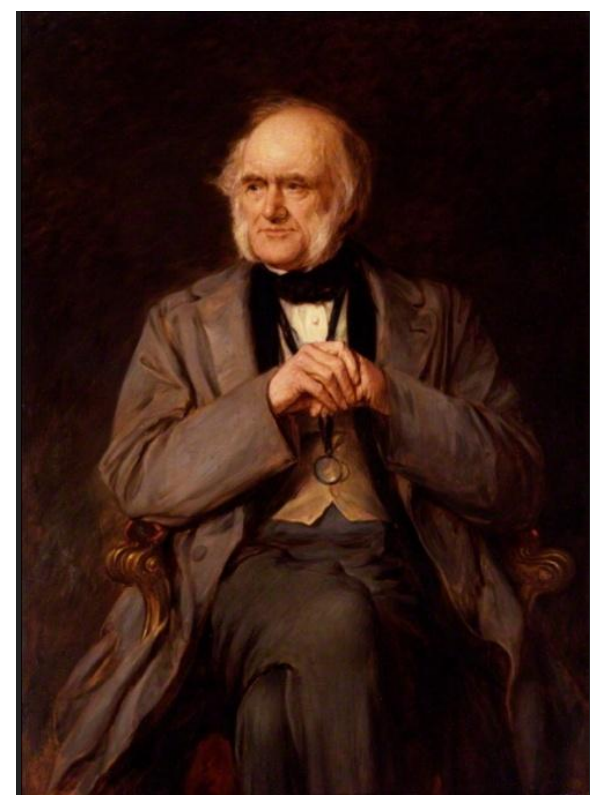

Fig.28. Sir Charles Lyell (1797-1875) 


\section{IARJSET \\ International Advanced Research Journal in Science, Engineering and Technology \\ ISO 3297:2007 Certified \\ Vol. 5, Issue 5, May 2018}

\section{ACKNOWLEDGEMENT}

This Research Paper is a collection of literature from various books and research papers published by eminent authors for whom I am giving due credit. The diagrams and graphs are drawn free hand by me looking at the originals of those authors who deserve the entire credit and I am highly indebted to them. I highly appreciate their excellent work and sincerely thank them through my paper. The authors in reference are:

1. David Bercovici, Dept. of Geology and Geophysics, Yale University, US

2. Mark Jellinek, Professor, Earth Ocean and Atmospheric Sciences, University of British Columbia, Canada.

3. Glyn Williams-Jones, Professor Undergraduate Committee, Chair and Co-ordinator, Centre for Hazards Research, Dept. of Earth Sciences, Simon Fraser University, Canada.

4. Hazel Rymer, Professor of Environmental Volcanology, Open University, UK.

5. Prof. Agust Gudmundsson, Chair of Structural Geology, Dept. of Earth Sciences, University of London.

Epilogue: Readers will be surprised to know that the author has so much affection to the subject that what more can be expected of him of celebrating his $75^{\text {th }}$ birthday (15 August 2014) on the foothills of a volcano in the United States. Not one volcano but two of them so near that I thought of climbing over each of their lava dome. I am producing herewith two photos of this geological wonder (Fig. ) with my photo in each of them. I started from my US residence at Foster City, central California-94404 on the morning of Friday the $15^{\text {th }}$ August 2014 and reached Siskiyou county in northern California a distance of nearly 300 miles $(480 \mathrm{~km})$ and reached Mount Shastha a stratovolcano of geological fame before noon driving nearly 5 hours. The brief details of the volcano is as under: The elevation is 14,179 Feet $(4.322 \mathrm{~km})$ above sea level and 9822 Feet $(2.994 \mathrm{~km})$ above the surrounding terrain; Volume: $350(\mathrm{~km})^{3}$. Second highest peak and most voluminous strato volcano; Last eruption: Year 1786 (Date not known)

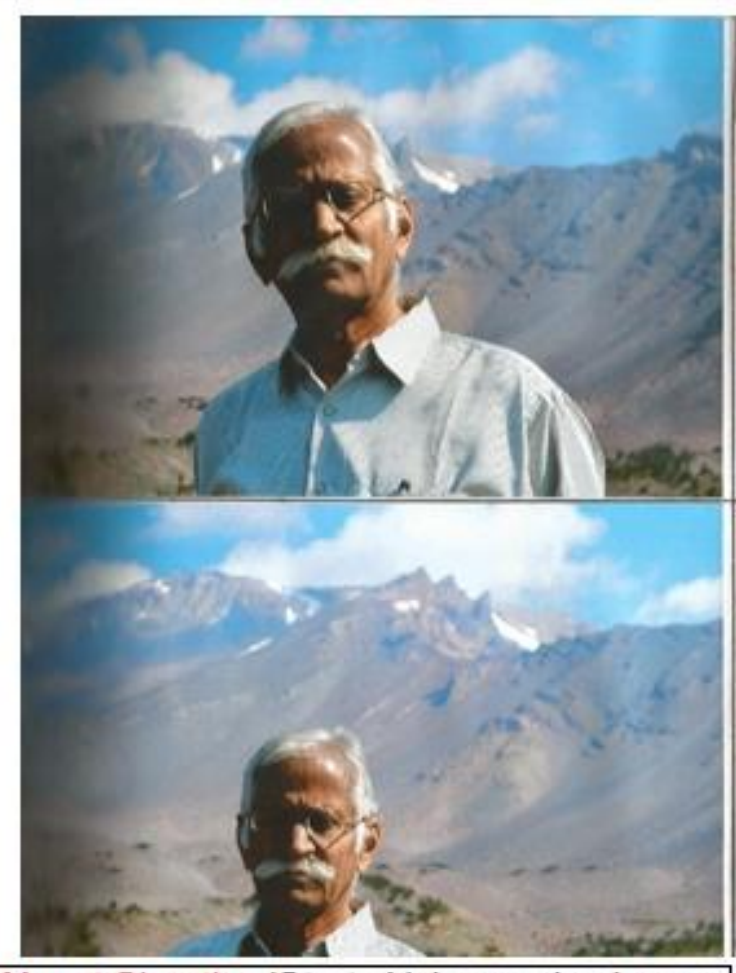

Mount Shastha (Strato Volcano also known as Composite Volcano) at Siskiyou county, Northern California, USA 96067 had a close look on my 75 th Birthday, Friday the 15th August 2014. Second highest peak and most voluminous Strato Volcano Last eruption: year 1786

Top: One side. Bottom: The other side

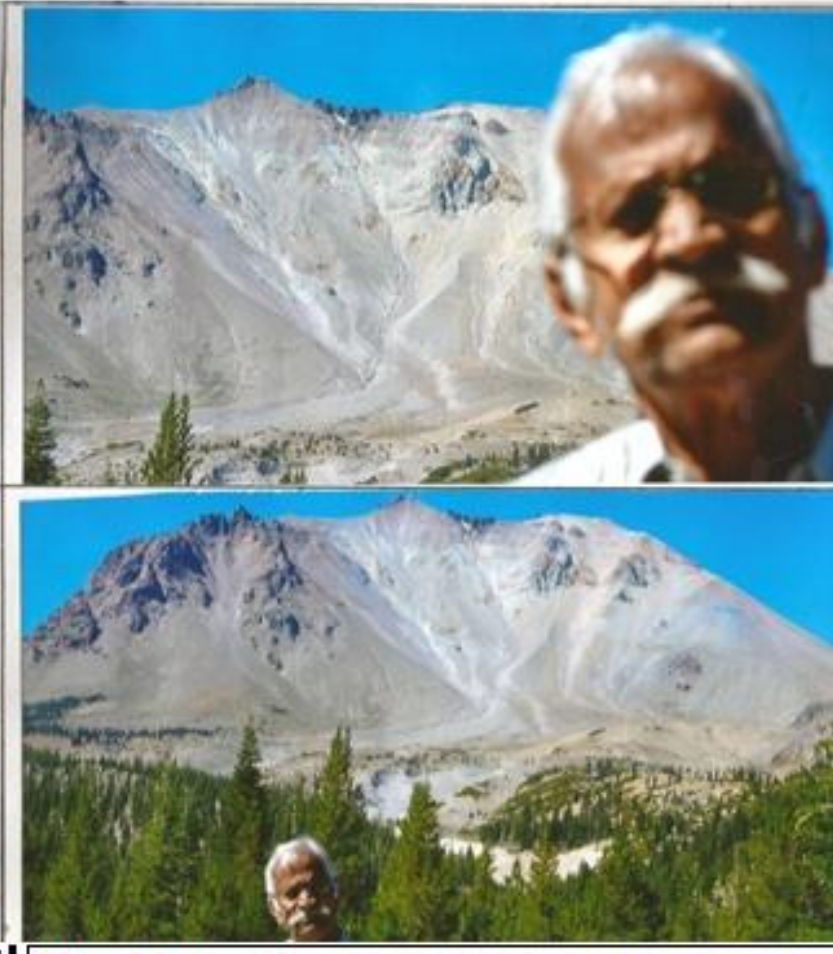

Mount Lassen (Strato Volcano also known as Composite Volcano) at Mineral, Northern California, USA 96063 had a close look on Saturday the 16th August 2014. One of the largest lava domes on Earth. Last eruption: 22 May 1915 Top: One side. Bottom: The other side

Fig. 29 Picture of Author's visit to Volcanoes, Mount Shastha and Mount Lassen 


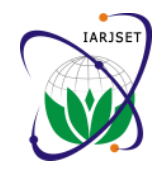

\section{IARJSET \\ International Advanced Research Journal in Science, Engineering and Technology \\ ISO 3297:2007 Certified \\ Vol. 5, Issue 5, May 2018}

A volcano's two sides (front and back) has to be seen. Hence drove few kilometers and reached the other side of the volcano and looked at it with wonder the mount formed by accretion of layers of lava over centuries.

As it was almost sunset stayed at a hotel nearby and decided to see the other volcano, Mount Lassen at Mineral county some $50 \mathrm{~km}$ from Mount Shastha. On the morning of the next day (16 August 2014) drove to Mineral county and reached Mount Lassen before noon. The Lassen peak is another geological wonder with the following details: Elevation:10,457 Feet $(3.187 \mathrm{~km})$ above sea level, 5229 Feet $(1.594 \mathrm{~km})$ above the surrounding terrain; Volume: 2 $(\mathrm{km})^{3}$; One of the largest lava domes on Earth. Last eruption: 22 May 1915.

I particularly watched for any plant life on the slopes of both the volcanoes, but not even a grass could be seen. No plant grows on lava.

\section{REFERENCES}

[1] Alyssa Navarro Tech Times, 6 June 2016

[2] Christiansen Eric H and W Kenneth Hamblin , "Earth's Dynamic Systems”, Pearson Prentice Hall, 10 ${ }^{\text {th }}$ Ed., 2004, ISBN: 0-13-142066-6; p.83, 618.

[3] Cook A.H. "Interiors of the Planets", Cambridge Univ. Press, 1980, ISBN:0 521 232147, p.40

[4] Eric Hand, "Deep Magma Chambers seen beneath Mount St. Helens" 4 Nov. 2015

[5] Gisselle Diamond, "How are Volcanoes’ Eruption Measured?” Pub. By Sciencing -Nature, 24 April 2017

[6] Glyn Williams-Jones and Hazel Rymer. "Detecting Volcano Eruption Precursors - A new method using Gravity and Deformation measurements", Elsevier Journal of Volcanology and Geothermal Research 113 (2006). P.379-389.

[7] Gudmundsson, "Magma Chambers: Formation, Local stresses, Excess Pressures and Compartments", Journal of Volcanology and Geotyhermal Research 237-238 (2012), p.19-41.

[8] Jacob. B. Lowenstern, Thomas W. Sisson and Shail Hurwitz - "Drilling into Magma, Probing Magma Reservoir to improve Volcano Forecasts.

[9] Janine L. Kavanagh, Samantha L. Engwell and Simon A. Martin, "A Review of Laboratory and Numerical modeling in Volcanoes, Solid Earth 9, 2018, p.531-571. 2.1 Volcanology as a Science p.532, 5. Magma Chambers, p. 539

[10] John Langone, Bruce Stutz and Andrea Gianopoulos, “The Theories of Everything” from National Geographic, ISBN: 978-1-4351-3339-6, Ed.2011, p. 328, 337.

[11] Lady Gryphon, "Gods and Legends", 22 Aug. 2016

[12] Mark Jellinek and David Bercovici, "Seismic Tremors and Magma Wagging during Explosive Volcanism", Nature, Mc Millan Publishers Limited, Feb.2011, p. 522-526.

[13] Paul W. Taylor, "Myths, Legends and Volcanic Activity - An example from northern Tonga", Vol.104, No.3, p.323-346.

[14] Poisson Statistics-Volcanoes. Real life maths, 20 April 2015.

[15] Prof. Stephen A. Nelson, "Natural Disasters", Tulane Univ., Page updated 14 Sep. 2015.

[16] Tilling Robert I. "Volcanoes", US Dept. of the Interior US Geological Survey 1998 (45 pages)

[17] Turcotte D.L., J.R. Ockendon and S.J. Cowley, “A mathematical of Volcanic Eruption”, Geophysics Journal Institute (1990) (103), p.211-217.

[18] United States Geological Survey (USGS)

[19] Wikipedia, "Eruption of Mount Vesuvius in 79", Edited on 5June 2018.

[20] Wikipedia, "Geothermal Gradient", Edited on 23 May 1998.

\section{BIOGRAPHY}

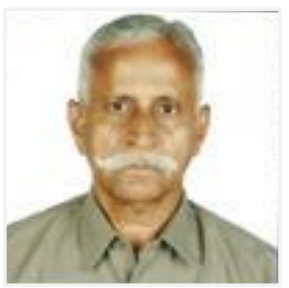

*Dr. (Prof.) V.C.A. Nair (b.15th Aug. 1939) is an Educational Physicist, Counselor, Research Guide and Consultant. He did his Masters in Physics from Mumbai University, India and Ph.D. from JJT University, Rajasthan also in India He is a Research Guide and distinguished alumni of JJT University. He is also a Chancellor designated Resource Person in the area of Physics in the University. He has to his credit over 4 decades of teaching Applied Physics in eminent Polytechnics in Mumbai and having taught nearly 16,000 students since 1965. He has published a number of research papers in Physics and Geophysics in International and UGC recognized Journals some of which can be seen in the net 'Google Search' when the name of the author is typed in that style. He is a Life Member of Indian Society for Technical Education which is an all India body. He had been to USA a number of times and visited eminent Universities such as Stanford, Harvard, MIT, University of California both at Berkeley and Los Angeles, University of Princeton at New Jersey and University of San Francisco. At present Dr. Nair is a Research Guide for Physics at JJT University, Rajasthan-333001, India. He is member of the Editorial Board of this Journal. His Ph.D. Thesis is in Geophysics and he is working on topics such as Tides, Clouds, Global Warming and Climate Change. - Editor.

*nairvca39@gmail.com 